\title{
Tethyan-to-boreal correlation in the Kimmeridgian using high-resolution sequence stratigraphy (Vocontian Basin, Swiss Jura, Boulonnais, Dorset)
}

\author{
C. Colombié · N. Rameil
}

\begin{abstract}
Ammonite biostratigraphy plays a central role in the definition of Jurassic stratigraphy. Nevertheless, the strong provincialism of European ammonite species during the Kimmeridgian is a longstanding problem in correlation attempts between the boreal and Tethyan faunal realms. Moreover, the sequence-stratigraphic interpretations for northern and southern Europe given in the Jurassic chronostratigraphic chart of Hardenbol et al. in SEPM Publ. 60 (chart) (1998) are different. The present study aims to resolve this correlation problem in order to better understand the connections between the boreal and the Tethyan realms during the Kimmeridgian. A sedimentological and high-resolution sequence-stratigraphic interpretation is presented for two unpublished sections (Cras d'Hermont and Roche de Mars) in the northern Swiss Jura, where recently discovered ammonites display both boreal and Tethyan influences. Then, these sections are correlated with the same time interval in the central Swiss Jura and Vocontian Basin, which belong to the Tethyan realm. Lastly, a long-
\end{abstract}

\section{Colombié $(\varangle)$}

UMR CNRS 5125 PEPS, Université Claude Bernard Lyon 1, Domaine Scientifique de La Doua, bât. Géode,

2 rue Raphaël Dubois, 69622 Villeurbanne Cedex, France

e-mail: claude.colombie@univ-lyon1.fr

N. Rameil

Département de Géosciences-Géologie et Paléontologie,

Université de Fribourg, Pérolles, 1700 Fribourg, Switzerland

Present Address:

N. Rameil

Institute for Geology, Mineralogy and Geophysics,

Ruhr-Universität Bochum, Universitätsstr. 150,

44801 Bochum, Germany distance transect is constructed between the Vocontian Basin, Swiss Jura, northern France, and southern England, the last two areas being part of the sub-boreal realm. The main results of this work are that: (1) thirdorder depositional sequences, and also higher-frequency sequences, can be correlated from the Tethyan to the boreal realm; (2) the sequence-stratigraphic interpretation given by Hardenbol et al. in SEPM Publ 60 (chart) (1998) for northern Europe seems to be accurate and agrees with the sequence-stratigraphic framework established in the Swiss Jura; (3) the Late Kimmeridgian of the Swiss Jura displays boreal influences; (4) integrated high-resolution sequence-stratigraphic and cyclostratigraphic studies are a valuable approach for bridging the correlation gap between northern and southern Europe.

Keywords Kimmeridgian · Tethyan-to-boreal stratigraphic correlation - Sequence stratigraphy · Cyclostratigraphy

\section{Introduction}

Ammonite biostratigraphy plays a central role in the definition of Jurassic stratigraphy. Nevertheless, the strong provincialism of European ammonite faunas during the Middle-Late Oxfordian and the Early Kimmeridgian has resulted in the definition of two separate zonal schemes based on the different groups of ammonites that occurred in the boreal (arctic areas and northern Europe) and Tethyan (southern Europe and Tethys margin) faunal provinces, respectively (Atrops et al. 1993) (Fig. 1). For the last few years, the discovery of boreal ammonites of the genus 


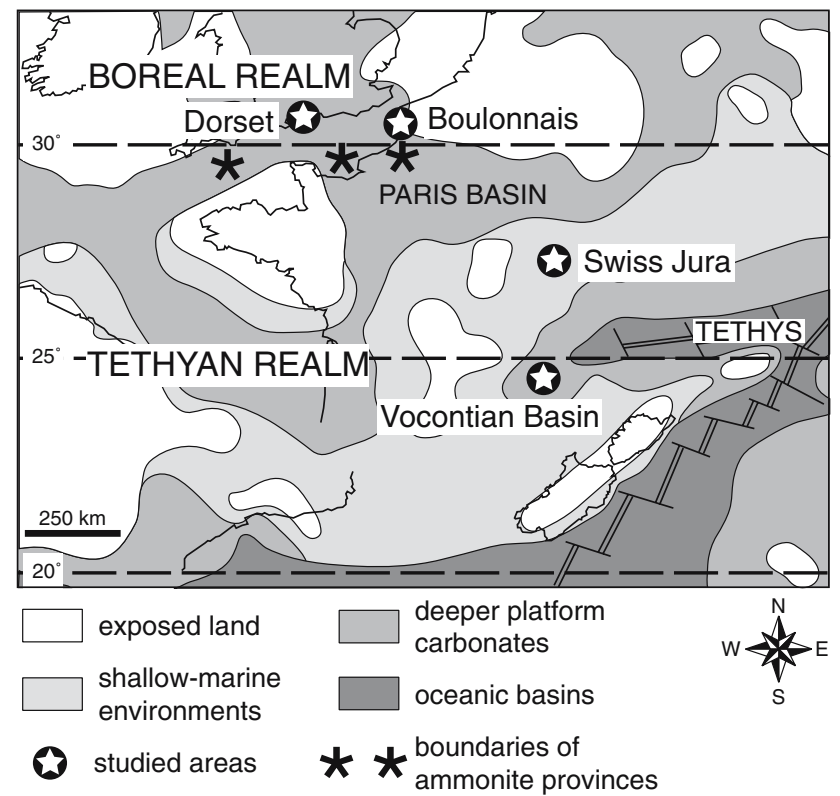

Fig. 1 Palaeogeographical location of Dorset, Boulonnais, Swiss Jura, Vocontian Basin, and the boreal and Tethyan realms during the Kimmeridgian, modified from Thierry et al. (2000) and Abbink et al. (2001)

Amoeboceras in sections that are traditionally located in the submediterranean faunal province provides important data for a more accurate correlation between the differing boreal-subboreal and submediterranean ammonite zonations (Atrops et al. 1993; Schweigert and Callomon 1997). However, further work is required to resolve the lasting problems of correlation.

The stratigraphic chart of Hardenbol et al. (1998) (Fig. 2) is an attempt to construct a state-of-theart biochronostratigraphic record of depositional sequences for the Jurassic of West European basins (Thierry 1999). The chart is subdivided in two parts: a "zonal biostratigraphy chart" and a "sequence chronostratigraphy chart", both calibrated to the time scale of Gradstein et al. (1994). The "sequence chronostratigraphy chart" focuses on third-order depositional sequences. These units are grouped into second-order transgressive-regressive cycles (Fig. 2). Each thirdorder sequence is plotted facing the corresponding ammonite zonal scheme for the boreal and Tethyan realms. In analogy to the differing Tethyan and boreal biozonations, there are also two differing sequencestratigraphic interpretations: in northern Europe, the Kimmeridgian includes seven third-order sequence boundaries (Kim 1-7). In southern Europe, only five sequence boundaries are given for the same interval (Kim 1-5). Moreover, most of the Kimmeridgian corresponds to a second-order transgression, which begins in the Middle Jurassic and ends in the uppermost Kimmeridgian. The location of the second-order maximum flooding differs in the boreal and Tethyan realms: in the Autissiodorensis ammonite zone in the boreal realm and in the Eudoxus zone in the Tethyan realm.

This study aims to resolve the contrasting sequencestratigraphic interpretations given by Hardenbol et al. (1998) for the Kimmeridgian of northern and southern Europe in order to better constrain changes in climate, relative sea-level, sediment production, supply, and accumulation, as well as palaeoenvironmental variables that controlled the dynamics of the European seas during the Late Jurassic. This is achieved by using high-resolution sequence stratigraphy to build a correlation between the biostratigraphically well-defined hemipelagic and pelagic deposits of the Vocontian Basin in France, the cyclic shallow-water carbonates from the Swiss Jura (both Tethyan realm), the basinal Kimmeridge Clay Formation in Dorset, as well as the more marginal Boulonnais (northern France) succession (both boreal realm) (Fig. 1).

\section{Geological setting}

The basis of this work is the sedimentological, sequence- and cyclostratigraphic interpretation of six Kimmeridgian sections that are located in the Swiss Jura: Péry-Reuchenette, Gorges du Pichoux, Noirvaux, Cras d'Hermont, Roche de Mars, and Sur Combe Ronde.

During the Kimmeridgian, the Jura Mountains area was a southwest-northeast trending carbonate platform, located between the Paris Basin to the northwest and the Ligurian segment of the Mesozoic Tethys to the southeast (Fig. 1). This slightly sloping platform was bounded in the south and SE by more or less continuous bioclastic and oolitic barriers, and by coral reefs (Enay et al. 1988; Meyer 2000). Despite the second-order sea level rise, which characterised most of the Kimmeridgian, and led in many Western European basins to the formation of marly and condensed sections, the Jura platform kept growing and only subtle changes in the stratigraphic record suggest an increasingly openmarine influence (Colombié and Strasser 2005).

The Jura Mountains can be subdivided into a northern, a central and a southern part (Wildi et al. 1989). The central and southern parts belong to the folded Jura belt, while the northern part constitutes the tabular Jura.

The Péry-Reuchenette and the Gorges du Pichoux sections are located to the northeast of Biel in the 


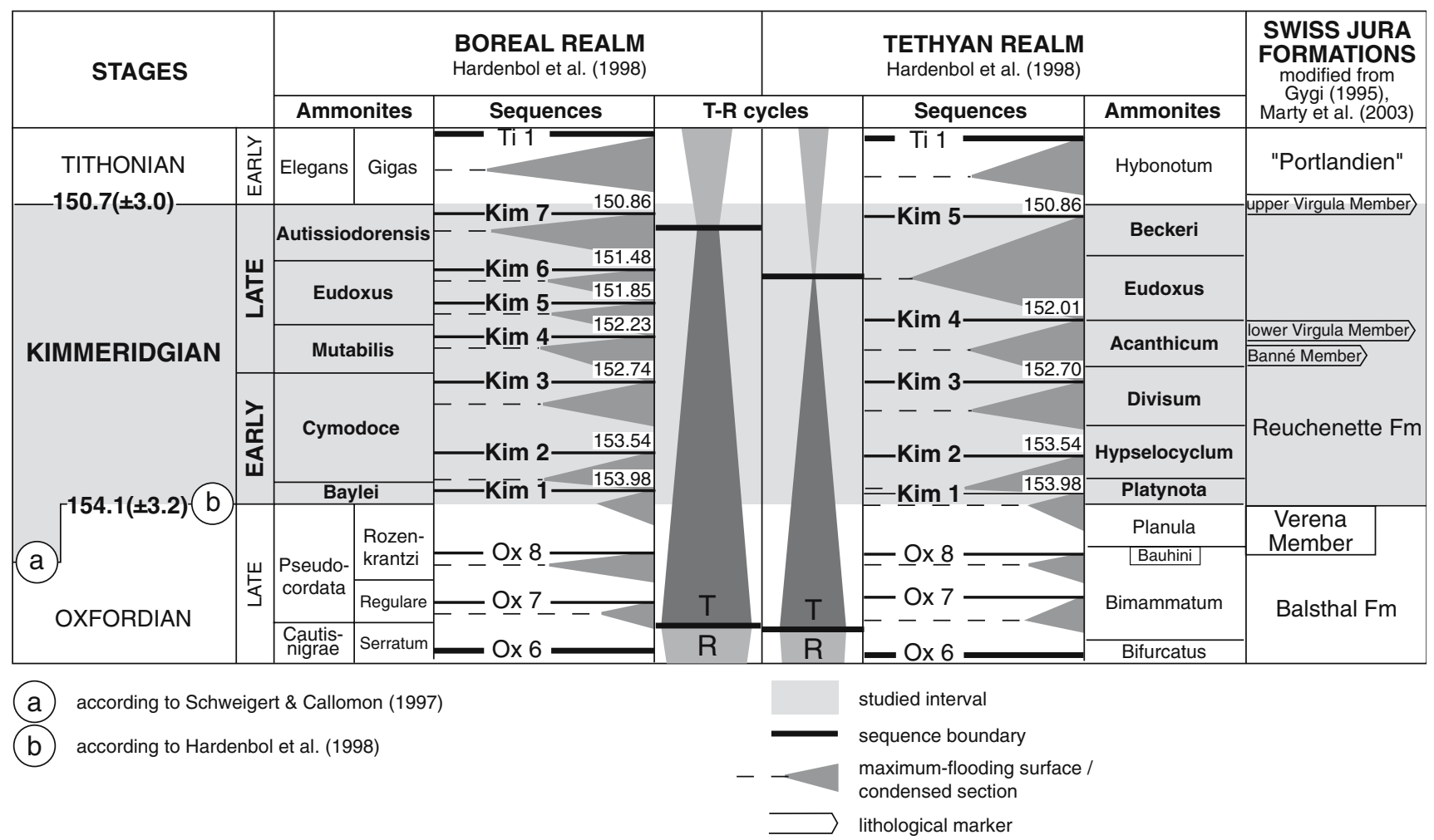

Fig. 2 Stratigraphic chart for the studied interval and associated formations in the Swiss Jura

central Swiss Jura (Fig. 3). There, the Kimmeridgian corresponds to the Reuchenette Formation, which is a thick succession (140 $\mathrm{m}$ on the average) of shallowwater marine limestone (Thalmann 1966; Gygi 1995). No detailed biostratigraphic data are available in these deposits but a recent sedimentological and high- resolution sequence-stratigraphic interpretation of the Péry-Reuchenette and Gorges du Pichoux sections has allowed the detailed correlation with three biostratigraphically well-dated sections in the Vocontian Basin in France and thus the definition of a precise stratigraphic framework (Colombié 2002; Colombié
Fig. 3 Geographical location of the studied sections in the Swiss Jura

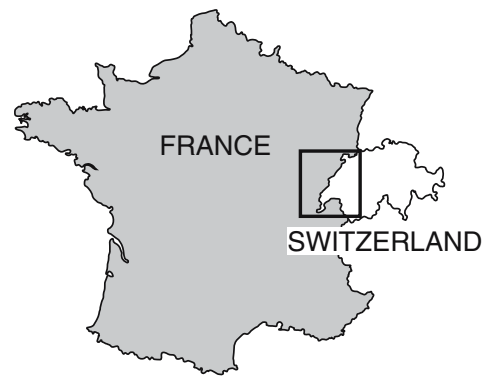

STUDIED SECTIONS

(1) Cras d'Hermont - Roche de Mars

(2) Sur-Combe-Ronde

(3) Gorges du Pichoux

(4) Péry-Reuchenette

(5) Noirvaux

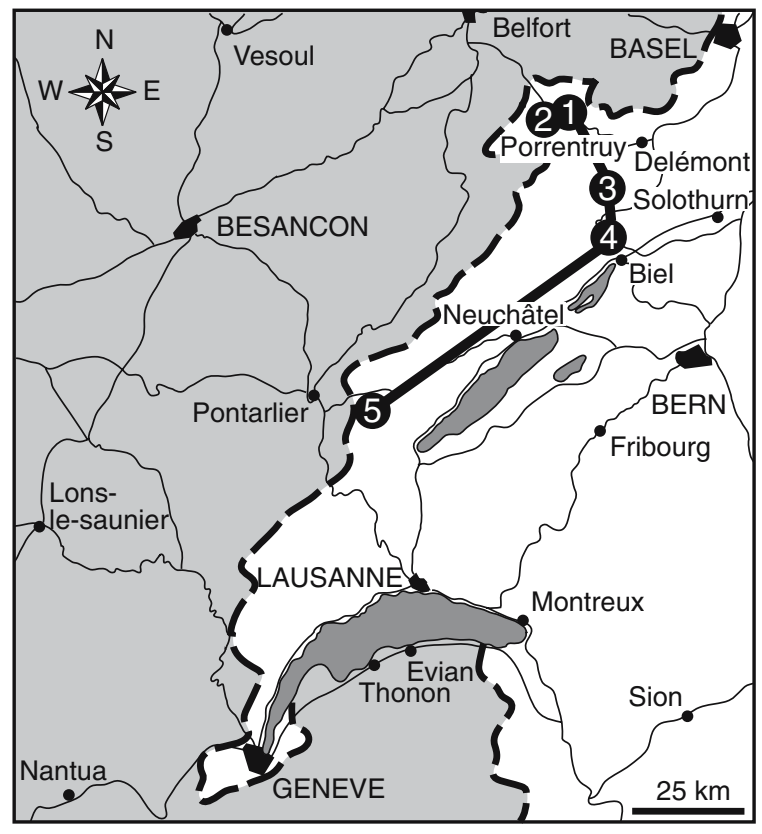


and Strasser 2003, 2005). The sedimentological, sequence- and cyclostratigraphic interpretation of the central Swiss Jura and Vocontian Basin sections has led to the definition of small-, medium-, and largescale depositional sequences, which are hierarchically stacked, suggesting an orbital control on sedimentation (Colombié 2002; Colombié and Strasser 2003, 2005). From the stacking pattern of sequences in the central Swiss Jura sections, the correlation with the biostratigraphically well-dated sections of the Vocontian Basin, and the comparison with the chronostratrigraphic chart of Hardenbol et al. (1998), it is concluded that the small- and medium-scale sequences coincide with the first and second eccentricity cycle, respectively [representing durations of 100 and $400 \mathrm{ka}$ and corresponding to the fifth and fourth order sequences of Vail et al. (1991)].

The Noirvaux section is located to the southeast of Pontarlier in the southern Swiss Jura (Fig. 3). Here, in the steep gorge of the Noiraigue River, large parts of the Late Jurassic (Middle Oxfordian-Middle Tithonian) are well exposed. The recent sedimentological and sequence-stratigraphic interpretation of the Late Kimmeridgian and Tithonian parts of this section (Rameil 2005) allows the correlation with the PéryRechenette and the Gorges du Pichoux sections (Colombié et al. 2004).

The Cras d'Hermont and Roche de Mars sections are located to the southeast of Porrentruy in the northern Swiss Jura (Fig. 3), which corresponds to the tabular Jura. Because of the low relief, the Kimmeridgian is incompletely exposed and poorly known. However, the Cras d'Hermont and Roche de Mars sections contain subboreal and submediterranean ammonites (Section de Paléontologie 2001; Marty and Diedrich 2001; Marty 2002), so they constitute a good relay in a Tethyan-to-boreal correlation. They are composed of essentially shallow water marine limestones, except for two argillaceous layers, which are the Banné and the lower Virgula Members. The Banné Member is between 5 and $10 \mathrm{~m}$ thick. It is composed of calcareous marl and argillaceous limestone, which contains abundant gastropods and pelecypods, and is interpreted as a shallow lagoon deposit (Marty and Diedrich 2001). The Banné Member occurs below the lower Virgula Member and is located in the Acanthicum ammonite zones (Gygi 1995; Marty and Diedrich 2001; Marty et al. 2003) (Fig. 2). The lower Virgula Member is $0.8-1 \mathrm{~m}$ thick and composed of calcareous marl and argillaceous limestone, with abundant oysters (Nanogyra nana). Gastropods, pelecypods, echinoids, and ammonites indicate marine depositional environments with normal salinity such as sheltered lagoons
(Section de Paléontologie 2001). The base of the lower Virgula Member is defined by a hard ground, which is located in the upper part of the Mutabilis zone (Schilleri horizon, Lallierianum subzone) (Marty 2002; Marty et al. 2003) (Fig. 2). While the ammonite specimens found in the Jura Mountains show a Tethyan affinity in the Early Kimmeridgian, they suggest boreal influences in the Late Kimmeridgian (Gygi 1995). Consequently, the boreal zonation is used in the upper part of the studied interval.

The Sur Combe Ronde section is located close to the Cras d'Hermont and Roche de Mars section (Fig. 3). The section presented in Fig. 10 was redrawn from the highly detailed, original log measured by the Section de Paléontologie in Porrentruy, Switzerland (W. Hug, personal communication). There, the lower Virgula Member contains ammonites that are characteristic of the Schilleri horizon, upper part of the Mutabilis zone (Marty 2002; Marty et al. 2003).

\section{Materials and methods}

A detailed sedimentological analysis has been performed on the unpublished Cras d'Hermont and Roche de Mars sections (Figs. 4, 5, 6, 7). They are 36 and $17 \mathrm{~m}$ thick, respectively. The upper part of the Cras d'Hermont section includes the Banné Member, while the lower Virgula Member occurs at the top of the Roche de Mars section. Therefore, these sections together represent a stratigraphic interval from approximately the Hypselocyclum to the upper part of the Acanthicum (or Mutabilis) ammonite zones (Fig. 2). Weathering profile, lithology, and sedimentary structures have been determined in the field, while the definition of microfacies is based on analyses of 121 rock slabs and 90 thin sections. Sedimentary facies in the Cras d'Hermont and Roche de Mars sections are similar to those recently studied in great detail in the Kimmeridgian of the central Swiss Jura (Colombié 2002; Colombié and Strasser 2005). The sedimentological interpretation of the Cras d'Hermont and Roche de Mars sections is therefore based on the facies model defined for the Péry-Reuchenette and Gorges du Pichoux sections (Colombié 2002; Colombié and Strasser 2005).

The evolution through time of depositional environments, discontinuity surfaces, and the stacking pattern of beds have led to the definition of several orders of depositional sequences, which are hierarchically stacked. The methodology used in this study follows the one proposed by Strasser et al. (1999) for shallow-water carbonates. The depositional sequences 


\begin{tabular}{|c|c|c|}
\hline \multicolumn{2}{|c|}{ SEDIMENTARY STRUCTURES } & $\begin{array}{l}\text { ALLOCHEMS } \\
\text { Skeletal grains }\end{array}$ \\
\hline =型 & & $\checkmark$ undifferen \\
\hline+7 & chalky limestone & bioc \\
\hline- & plan & $\smile$ oyster \\
\hline$n$ & & $\begin{array}{l}\text { bivalve in } \\
\text { life position }\end{array}$ \\
\hline U & undifferentiated & od \\
\hline a & perforation & undifferentiated \\
\hline s & worm tube & benthic foraminifer \\
\hline 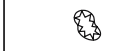 & geo & $\begin{array}{l}\text { undifferenci } \\
\text { green alga }\end{array}$ \\
\hline$\underset{\gamma}{\curvearrowright}$ & bird's eyes & Marinella \\
\hline$\Delta$ & tepee & ans \\
\hline 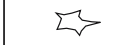 & circum-granular crack & coral \\
\hline$\approx$ & evaporite pseudomorph & brachiopod \\
\hline$>$ & cross bedding & echinoderm \\
\hline & current ripple & echinoid spine \\
\hline$\overline{\bar{\uparrow}}$ & $\begin{array}{l}\text { planar bedding } \\
\text { normal graded bedding }\end{array}$ & \multirow{6}{*}{$\begin{array}{cl}\text { Non-skeletal grains } \\
\odot \quad \text { peloid } \\
\odot \quad \text { oncoid } \\
\odot \text { ooid } \\
8 \text { grapestone } \\
\text { black pebble } \\
\text { lithoclast } \\
\text { coal }\end{array}$} \\
\hline \multicolumn{2}{|c|}{ LITHOLOGY } & \\
\hline 1,1 & limestone & \\
\hline$\overline{111}$ & dolomitic limestone & \\
\hline 둘 & $\begin{array}{l}\text { argillaceous and } \\
\text { dolomitic limestone }\end{array}$ & \\
\hline 星-1 & argillaceous limestone & \\
\hline 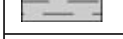 & mar & \multirow{2}{*}{$\begin{array}{ll}\text { RELATIVE ABUNDANCE } \\
\text { present } \\
\text { common } \\
\text { abundant } \\
\text { very abundant }\end{array}$} \\
\hline \multirow{4}{*}{\multicolumn{2}{|c|}{\begin{tabular}{|cl}
\multicolumn{2}{|c}{ TEXTURE } \\
m & marl \\
M & mudstone \\
W & wackestone \\
P & packstone \\
G & grainstone
\end{tabular}}} & \\
\hline & & SEQUENCE STRATIGRAPHY \\
\hline & & $\begin{array}{l}\text { MFD } \\
\text { deposit }\end{array}$ \\
\hline & & $\begin{array}{ll}\text {-SB- } & \text { sequence boundary } \\
\text { SB } & \text { sequence-boundary } \\
\text { zone }\end{array}$ \\
\hline
\end{tabular}

Fig. 4 Legend of the studied sections

are first defined independently in each section and then correlated to filter out beds that result from autocyclic processes such as progradation or lateral migration of sedimentary bodies (Ginsburg 1971; Pratt and James 1986; Strasser 1991) or to identify local and/ or regional gaps in the sedimentary record. Based on the high-resolution sequence stratigraphic interpretation and lithological markers, the Cras d'Hermont and Roche de Mars sections are then correlated with the Gorges du Pichoux, Péry-Reuchenette, and Noirvaux sections that are located in the central and southern Swiss Jura and that are known from earlier work (Colombié 2002; Colombié and Strasser 2005; Rameil 2005) (Figs. 8, 9).
On the basis of ammonite zones, the high-resolution sequence stratigraphic interpretation proposed for the above sections is compared to the sequence-stratigraphic interpretation given by Hardenbol et al. (1998) for the Kimmeridgian of southern and northern Europe. By counting the depositional sequences identified in this work between dated levels (i.e. boundaries of ammonite zones or subzones and third-order sequence boundaries), the duration of the different orders of depositional sequences can be inferred. A cyclostratigraphic interpretation thus becomes possible, resulting in a narrow time framework, which is compared with the sequence-stratigraphic interpretation given by Williams et al. (2001) for the Kimmeridgian of the Boulonnais (northern France) and Dorset (southern England), and with the cyclostratigraphic interpretation of the Kimmeridge Clay Formation proposed by Weedon et al. (2004).

\section{Facies evolution in the Cras d'Hermont and Roche de Mars sections}

The Cras d'Hermont and Roche de Mars sections are mainly composed of mudstones and bioclast-peloid wackestones to packstones, which contain gastropods, pelecypods, foraminifers, and echinoderms. These facies are representative of sheltered to semi-restricted lagoons, which can be differentiated according to content of echinoderm debris (Colombié 2002; Colombié and Strasser 2005).

The lower part of the Cras d'Hermont section is particularly soft (Fig. 5). The first $5 \mathrm{~m}$ are characterised by a relatively high content of echinoderm debris. This interval also shows three hard grounds, which are indicated by intense bioturbation, pelecypod encrustation and boring, iron mineralisation, and/or pelecypods in life position. The $2 \mathrm{~m}$ below the third hardground show few bioclasts. Between 9 and $11 \mathrm{~m}$, beds of massive limestone precede $4 \mathrm{~m}$ of fossil-free mudstones. From 18 to $21 \mathrm{~m}$, alternations of argillaceous limestone and limestone are characterised by many hardgrounds, which display the same sedimentary features as the hardgrounds that occur in the lower part of the section.

The upper part of the Cras d'Hermont section includes the Banné Member, unfortunately poorly exposed (Fig. 6). Moreover, faults in the upper part of this interval complicate the sequence-stratigraphic analysis. Consequently, the thicknesses and the number of argillaceous limestone layers, which form the Banné Member, should be regarded as a field-based interpretation. The upper part of the Cras d'Hermont 
Fig. 6 Cras d'Hermont section (part II)
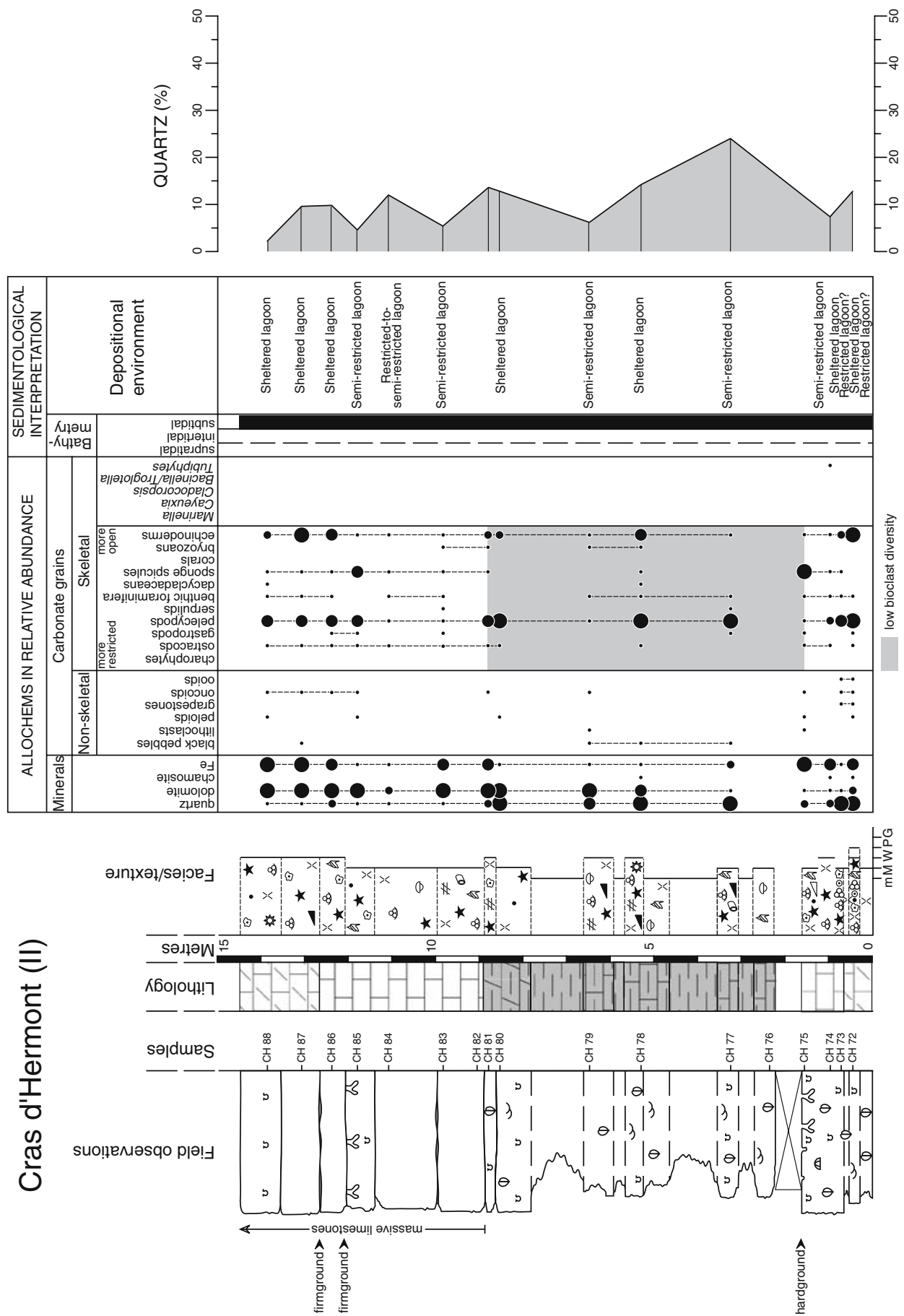

\begin{tabular}{|c|c|c|c|c|c|c|c|}
\hline sәэuәnbəs әреэs-ןeus & 尺ి & d & $\stackrel{\circ}{\circ}$ & $\stackrel{\infty}{\sigma}$ & & T & 0 \\
\hline səouənbəs ә|еоs-un!̣pəW & \multicolumn{3}{|c|}{ ما } & \multicolumn{3}{|c|}{$\nabla$} & \\
\hline
\end{tabular}

\begin{tabular}{|c|c|}
\hline Кydeג6!!eגısouı!า & ıәquәW ə઼uueg \\
\hline әuoz әा!uowய & ग $\forall$ \\
\hline ә6еis & NIX $\exists \perp \forall\urcorner$ \\
\hline
\end{tabular}


section begins with a massive limestone bed, which is bored at the top, and covered by the Banné Member. The Banné Member is composed of alternations of calcareous marls and argillaceous limestone, which are reddish to dark grey and characterised by abundant pelecypods, brachiopods, and gastropods. The argillaceous limestones show mudstone or wackestone texture and are characterised by black pebbles (i.e. blackened peloids and skeletal fragments that indicate ancient coastal and terrestrial environments (Strasser and Davaud 1983; Strasser 1984) and relatively low bioclast diversity. The uppermost part of the Cras d'Hermont section is composed of thick beds of massive limestone, which are separated from each other by argillaceous joints and/or firmgrounds.

The Roche de Mars section begins with planar laminations and bird's eyes that indicate intertidal to supratidal, tidal flat environments (Fig. 7). These structures are associated with a low diversity of bioclasts. The lower Virgula Member occurs in the upper part of the Roche de Mars section, just above a hardground, which is indicated by oxidation and oyster encrustations. It consists of calcareous marls and argillaceous limestones, which contain plenty of oysters (Nanogyra nana). Above the lower Virgula Member, the Roche de Mars section is mainly composed of relatively thick, massive limestone beds.

\section{Sequence-stratigraphic interpretation of the Cras d'Hermont and Roche de Mars sections}

Due to exposure gaps and relatively small facies contrasts, the sequence stratigraphic interpretation of the Cras d'Hermont and Roche de Mars sections is particularly difficult. Small facies contrasts are characteristic of the Kimmeridgian of the Swiss Jura. At this time, carbonate production and accumulation on the Jura platform were influential to maintain keep-up with the second-order transgression that started in the Late Oxfordian and ended in the Late Kimmeridgian (Colombié and Strasser 2005). Therefore, mediumscale and small-scale sequences are defined according to variations in bed thicknesses, discontinuities (such as firmgrounds and hardgrounds), changes in texture and bioclast diversity, and evolution of depositional environments through time (Figs. 5, 6, 7). Thin beds and restricted or sub-aerial depositional environments, which are characterised by low bioclast diversity, microbial mats and/or desiccation features, indicate reduced accommodation. Variations in texture from mudstone to wackestone-packstone, or vice versa, may correspond to an increase or decrease of water depth, suggesting a gain or loss in accommodation, respectively. Hardgrounds and firmgrounds are characteristic of relatively reduced accumulation rates, which may indicate decreasing accommodation.

\section{Quartz content variations in the Cras d'Hermont and Roche de Mars sections}

Variations in the relative abundance of quartz in the Kimmeridgian of the central Swiss Jura reflect platform dynamics (Colombié 2002). Moreover, Williams et al. (2001) show that sequence boundaries in the Kimmeridgian of southern England correspond to coarser quartz layers. In view to correlate the Kimmeridgian between the Swiss Jura and southern England, quartz content fluctuations in the Cras d'Hermont and Roche de Mars sections have been analysed.

Percentages of quartz were established with a point counter on the basis of 500 steps and are plotted in Figs. 5, 6 and 7. They decrease from the base to the top of the composite section (including the Cras d'Hermont and Roche de Mars sections). Percentages in the lower part of the Cras d'Hermont section can reach $41 \%$ and show two peaks (Fig. 5). The first one occurs at around $6 \mathrm{~m}$ and reaches $30 \%$. The second one lies between 19 and $21 \mathrm{~m}$ and shows values between 30 and $41 \%$. The upper part of the Cras d'Hermont section is characterised by percentages that vary from 2 to $24 \%$, with a peak defining the Banné Member (Fig. 6). Two peaks appear in the Roche de Mars section. The first one corresponds to $17 \%$ and occurs at around $4 \mathrm{~m}$. The second one, with only $14 \%$, is located at $9 \mathrm{~m}$ (Fig. 7).

The highest values in quartz content, which are observed in the Cras d'Hermont and Roche de Mars sections, do not always correspond to sequence boundaries, as it does in the central Swiss Jura and southern England (Williams et al. 2001; Colombié 2002) (Figs. 5, 6, 7). If it is not controlled by sea level oscillations, the input of detrital material can be influenced by climate and tectonics (Hillgärtner 1999). Climate, through erosion, alteration, and runoff, can control general trends in abundances of quartz. Increased quartz input can also reflect times of intensified uplift of local footwall sources (e.g. Collier and Dart 1991; Ravnås et al. 2000), or sediment-source switching (Macquaker et al. 1998). At last, changes in abundances of quartz can be due to variable aeolian transport, stratum-limited diagenesis, variable biological concentration or dilution with biogenic components (Macquaker et al. 1998). Unfortunately, available data 

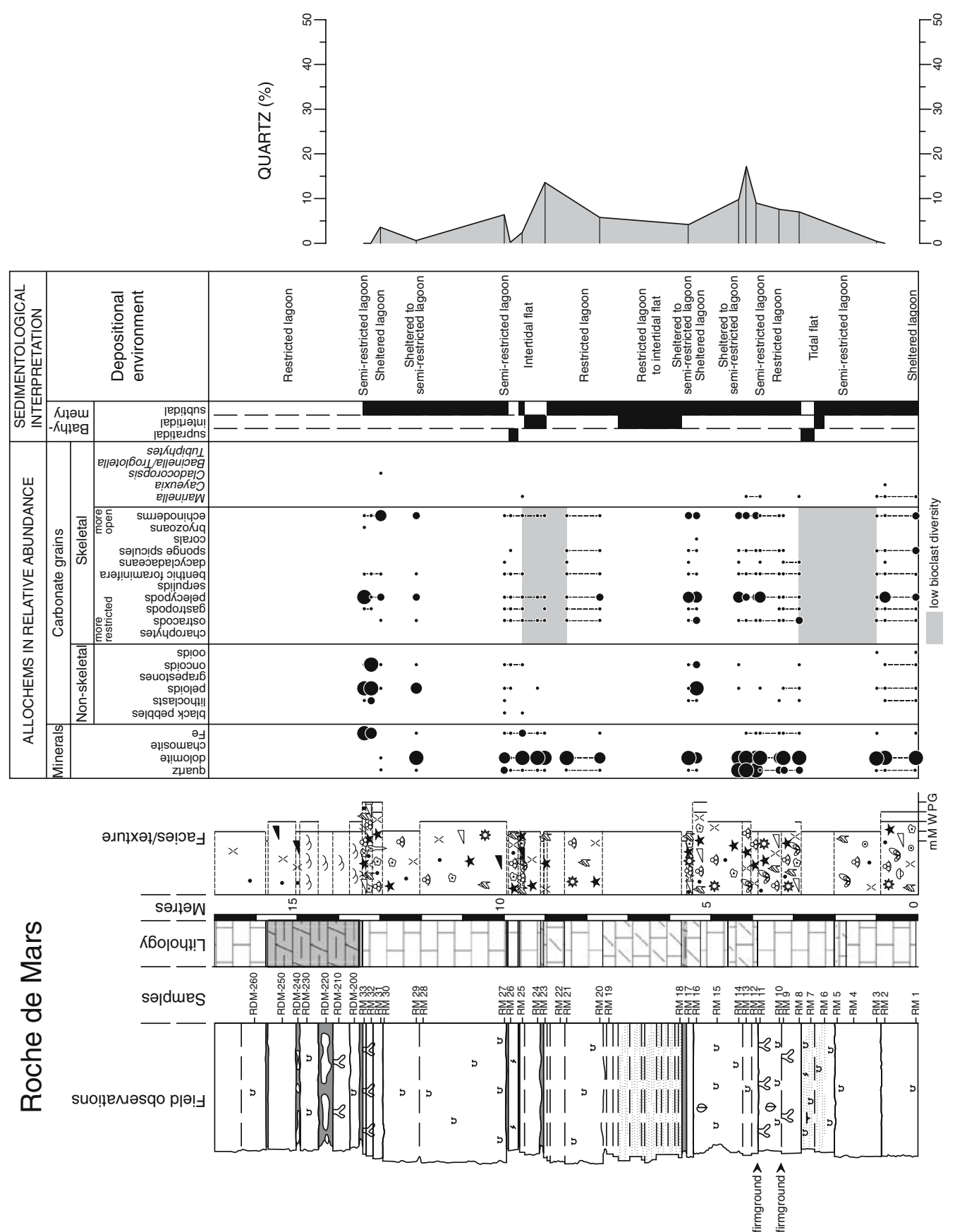

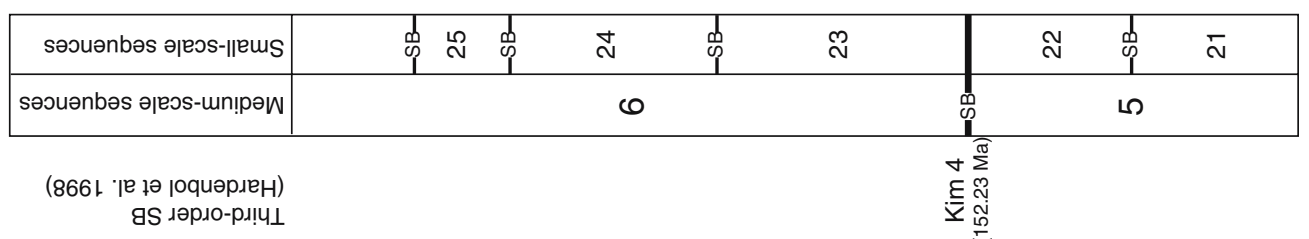

\begin{tabular}{|c|c|}
\hline 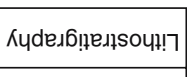 & 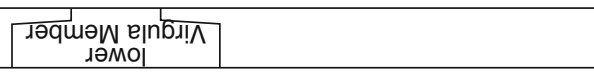 \\
\hline әиоz әңциошин & s!!!qeınW \\
\hline әбеts & 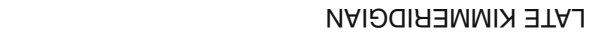 \\
\hline
\end{tabular}

Fig. 7 Roche de Mars section 
on the Cras d'Hermont and Roche de Mars sections do not allow favouring one of these controlling factors over any other. It is sure, however, that variations in quartz content are no reliable tool to correlate between the northern Swiss Jura and southern England.

\section{Correlation between Kimmeridgian sections of the southern, central, and northern Swiss Jura Mountains}

\section{Correlation between the Cras d'Hermont, Gorges du Pichoux, and Péry-Reuchenette sections}

Using lithological markers, the Cras d'Hermont section is correlated with the lower part of the Gorges du Pichoux section and further with the Péry-Reuchenette section (Fig. 8).

Two distinctive intervals are defined in the lower part of the Gorges du Pichoux section. The first one is located between 13 and $21 \mathrm{~m}$. It is composed of dark argillaceous limestone, strongly bioturbated, and contains abundant pelecypods and brachiopods (Colombié 2002). This interval is located just below $3 \mathrm{~m}$ of massive limestone, which is for the most part representative of restricted depositional environments (Colombié 2002). According to the correlation between the central Swiss Jura and the Vocontian Basin sections, this first interval coincides with the upper part of the Hypselocyclum ammonite zone (Colombié 2002; Colombié and Strasser 2003, 2005). Moreover, it is interpreted as the maximum-flooding deposit of the first large-scale sequence that is located between the thirdorder sequence boundaries Kim 1 and Kim 3 of Hardenbol et al. (1998) (Colombié 2002; Colombié and Strasser 2005). This interval is correlated with the first $9 \mathrm{~m}$ of particularly soft limestone of the Cras d'Hermont section, which occur below $3 \mathrm{~m}$ of fossilfree limestone that marks a shift to more restricted depositional environments.

The second distinctive interval in the lower part of the Gorges du Pichoux section is situated between 42 and $50 \mathrm{~m}$ and corresponds to argillaceous and dolomitic limestones that contain abundant brachiopods, pelecypods and sponge spicules, and precede a sudden increase in bed thicknesses (Colombié 2002) (Fig. 8). This interval includes two small-scale sequences that correspond to $200 \mathrm{ka}$ (i.e. two $100 \mathrm{ka}$ eccentricity cycles) (Colombié 2002; Colombié and Strasser 2005). It is located in the Acanthicum ammonite zone and overlies the transgressive surface of the second large-scale sequence, which follows the medium-scale sequence boundary equivalent to Kim 3 of Hardenbol et al. (1998), (Colombié 2002, Colombié and Strasser 2003, 2005). According to its lithology and stratigraphic position, it would be equivalent to the Banné Member, which occurs in the upper part of the Cras d'Hermont section.

In the nearby Combe de Vâ Tche Tchâ section, which is located to the east of Porrentruy, $6 \mathrm{~km}$ away from the Cras d'Hermont and Roche de Mars section, the Banné Member contains eleven marl-limestone alternations, which are between 32 and $85 \mathrm{~cm}$ thick (Marty and Diedrich 2001). These alternations would correspond to elementary sequences (Hug 2003). Assuming that an elementary sequence is the sedimentary expression of the astronomical precession cycle, i.e. $20 \mathrm{ka}$ [as defined in the Jura Mountains from the middle Oxfordian to the Valanginian by Strasser (1994), Pasquier and Strasser (1997), Pittet and Strasser (1998), Hillgärtner (1999), Colombié (2002), and Hug (2003)], the duration of the Banné Member would be about $200 \mathrm{ka}$, which is the same as its equivalent in the central Swiss Jura. Another argument supporting the above correlation is that the maximumflooding deposits of medium-scale sequences 2 and 3 are located, in the Gorges du Pichoux section as well as in the Cras d'Hermont section, in small-scale sequences 8 and 11, respectively (Fig. 8).

Correlation between the Roche de Mars, Noirvaux, Gorges du Pichoux, Péry-Reuchenette, and Sur Combe Ronde sections

The facies evolution in the Roche de Mars and the upper part of the Gorges du Pichoux section is different. The Roche de Mars section is therefore firstly correlated with the Noirvaux section, which is located to the southeast of Pontarlier in the southern Swiss Jura (Fig. 3), and subsequently with the Gorges du Pichoux, Péry-Reuchenette, and Sur Combe Ronde sections (Fig. 9).

The lower part of the Noirvaux section contains three argillaceous layers, which are probably equivalent to the three more argillaceous intervals of the upper part of the Roche de Mars section (Fig. 9). In both sections, the first argillaceous layer is associated with thinly laminated deposits, which are representative of tidal flat environments. Moreover, two to three massive limestone beds occur between the first and the second argillaceous layer. Lastly, the third argillaceous layer of the Noirvaux section corresponds to the lower Virgula Member that crops out in the upper part of the Roche de Mars section as well (Rameil 2005). 

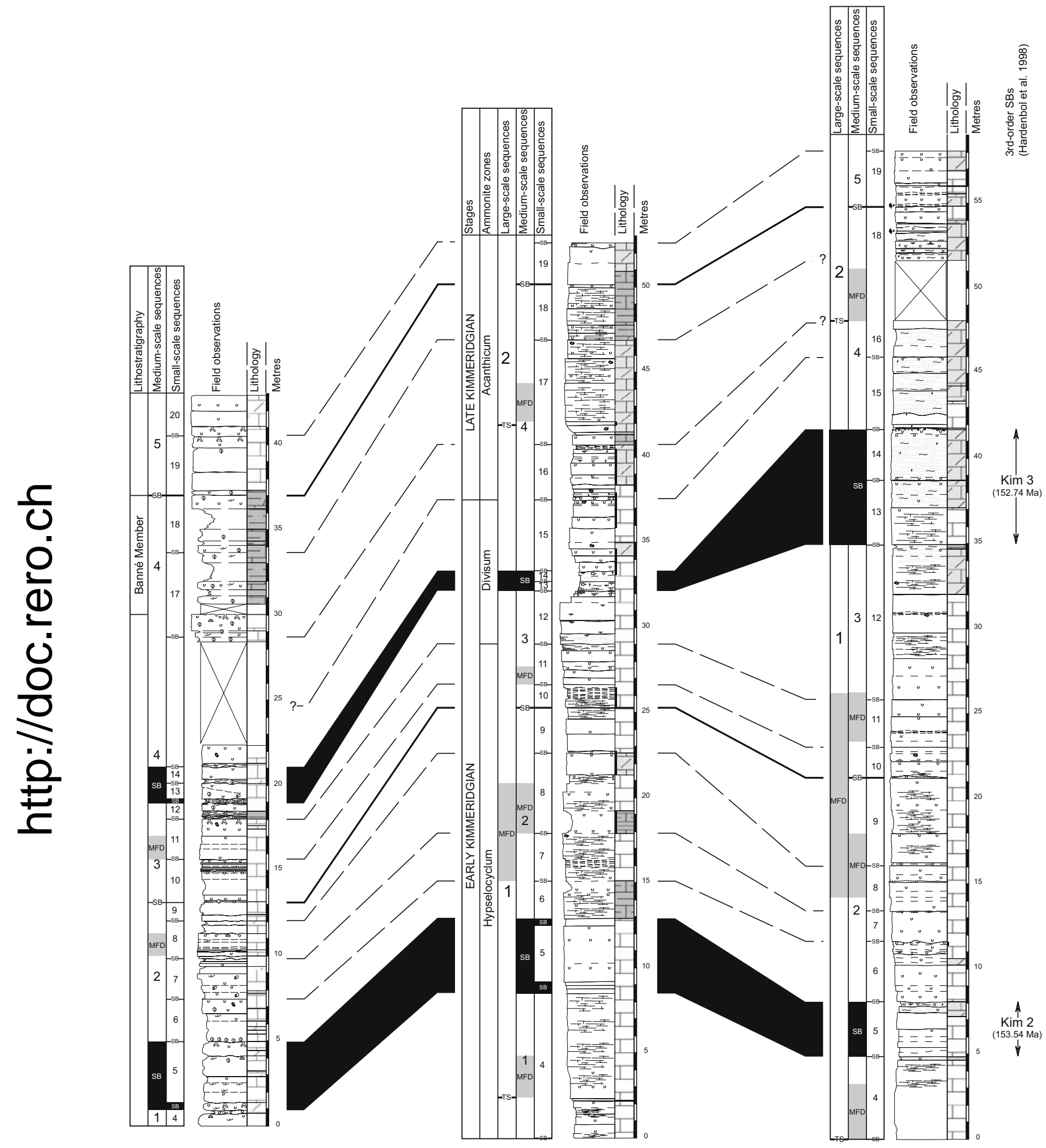

Cras d'Hermont

Gorges du Pichoux

Péry-Reuchenette

Key:

MFD maximum-flooding deposit -SB- sequence boundary

-TS- transgressive surface $\quad$ SB sequence boundary zone

Fig. 8 High-resolution sequence-stratigraphic correlation between the Cras d'Hermont, Gorges du Pichoux, and Péry-Reuchenette sections 


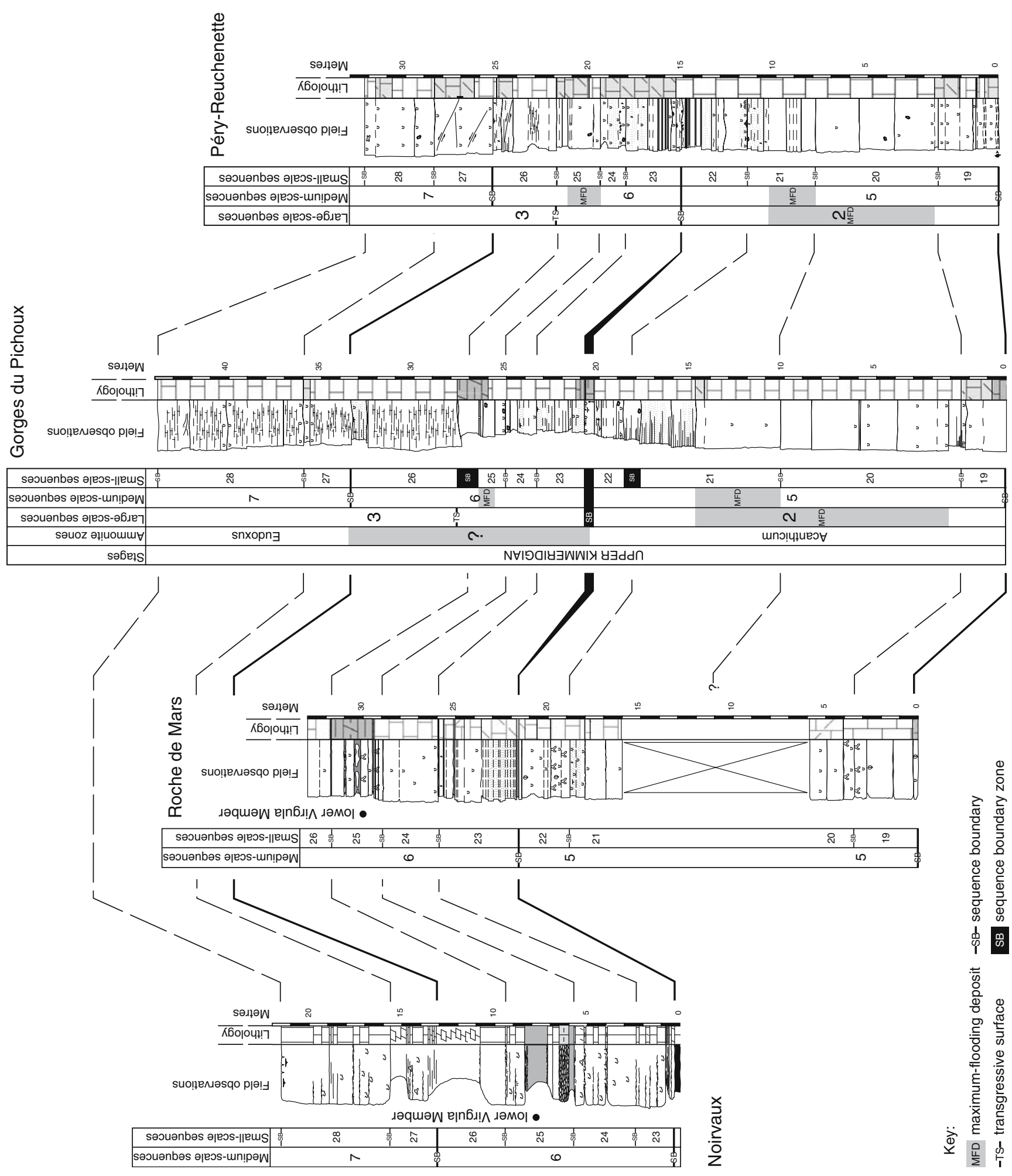

Fig. 9 High-resolution sequence-stratigraphic correlation between the Noirvaux, Roche de Mars, Gorges du Pichoux, and PéryReuchenette sections

The Gorges du Pichoux and the Péry-Reuchenette sections are located in the central Swiss Jura (Fig. 3). There, the Kimmeridgian corresponds to the Reuch- enette Formation (Thalmann 1966; Gygi 1995). Precise biostratigraphic dating is not possible, but the lower and upper boundaries of this formation correspond to 
lithological marker beds that are thought to be more or less isochronous (Gygi 2000). The lower boundary of the Reuchenette Formation coincides with the top of the white oolitic limestones of the Late Oxfordian Verena Member (Fig. 2). The member is characterised by an abrupt texture change (from packstone/grainstone to mudstone), the development of restricted environmental conditions, and an increase of quartz content (Colombie 2002). The upper boundary of this formation is indicated by the "Banc à Nérinées" (Dauwalder and Remane 1979), a heavily bored hardground (Meyer 1994), the "Marnes à Exogyra virgula" (or upper Virgula Member that is stratigraphically higher than the lower Virgula Member mentioned above) (Aubert 1932, 1950; Thalmann 1966), and/or the appearance of the "Calcaires en Plaquettes", thinly bedded peritidal limestones and dolostones attributed to the base of the "Portlandien" (i.e. Tithonian) (Fig. 2).

Two distinct lithological units are identified in each of the central Swiss Jura sections (Colombié and Strasser 2005). The lower unit is characterised by thin to moderately thick beds, a relatively high content of siliciclastic grains, many desiccation structures, and dolomite. This interval displays two general deepening-shallowing trends that are interpreted as the first two large-scale sequences, which in turn consist of the first five medium-scale sequences (Figs. 8, 9). The upper boundary of these large-scale sequences corresponds to an interval of relatively thin and marly beds that are expressed as depressions in the weathering profile (Fig. 9). The upper lithological unit of the Kimmeridgian in the central Swiss Jura is characterised by thick beds of massive limestone and the quasi-disappearance of terrigenous material, desiccation structures, and dolomite. Conversely, carbonate-producing organisms such as green algae and corals are common. This interval corresponds to a general deepeningshallowing trend that is interpreted as the third largescale sequence, including medium-scale sequences $6-8$ (Fig. 9).

The boundary between the lower and the upper lithological units precedes the most important increase in accommodation that is recorded in the Kimmeridgian of the central Swiss Jura, as indicated by the thick beds and the most open-marine facies in medium-scale sequence 7 (Fig. 10). The correlation between the central Swiss Jura and the Vocontian Basin sections show that this major increase in accommodation occurs most probably in the Eudoxus ammonite zone and corresponds to the second-order maximum flooding recorded in most of the other West-European basins (Colombié 2002; Colombié and Strasser 2003, 2005).
The Noirvaux section shows the same lithological units as the Gorges du Pichoux and Péry-Reuchenette sections. Consequently, the boundary between the lower and the upper lithological unit is used as a guideline to correlate these sections (Fig. 10). According to this correlation, the lower Virgula Member, which occurs in the upper part of the Noirvaux and Roche de Mars section, corresponds in the Gorges du Pichoux and Péry-Reuchenette sections to increasing bioclast diversity and bed thickness. This interval is interpreted as the maximum-flooding deposit of medium-scale sequence 6 that belongs, according to the correlation between the Swiss Jura and Vocontian Basin sections, to the Acanthicum or the Eudoxus ammonite zone (Fig. 9). Because of the strong provincialism of the European ammonite faunas during the Kimmeridgian, the boundary between the Acanthicum (equivalent to the Mutabilis zone in northern Europe) and Eudoxus zones in the Vocontian Basin is poorly defined (F. Atrops, personnal communication). The uncertainty interval for the position of this boundary corresponds to medium-scale sequence 6 (Fig. 9). However, the comparison of the high-resolution correlation between the southern, central, and northern Swiss Jura sections with the ammonite biostratigraphy defined in the Sur Combe Ronde section, which is located close to the Cras d'Hermont and Roche de Mars section in the northern Jura, and with the chronostratigraphic chart of Hardenbol et al. (1998) shows that the sequence boundary between medium-scale sequences 5 and 6 is located at the top of the Mutabilis ammonite zone (below the Schilleri horizon) and corresponds probably to Kim 4 defined by Hardenbol et al. (1998) for northern Europe (Kim $4_{\text {boreal }}$ ), and not to Kim 4 defined by the same authors for southern Europe (Kim 4 $4_{\text {Tethyan }}$ ) (Fig. 10). According to the cyclostratigraphic interpretation of the Swiss Jura sections, smallscale sequences correspond to $100 \mathrm{ka}$ eccentricity cycles, and medium-scale sequences to $400 \mathrm{ka}$ eccentricity cycles (Colombié 2002; Colombié and Strasser 2003, 2005; Rameil 2005). In the chronostratigraphic chart of Hardenbol et al. (1998), Kim $4_{\text {boreal }}$ and Kim $4_{\text {Tethyan }}$ are separated by $220 \mathrm{ka}$ (Fig. 2). In all studied sections, Kim $4_{\text {Tethyan }}$ is therefore located at the top of small-scale sequence 24 , two small-scale sequences or $200 \mathrm{ka}$ above the sequence boundary between mediumscale sequences 5 and 6 that corresponds to Kim $4_{\text {boreal }}$. Kim $4_{\text {Tethyan }}$ is included in the maximum-flooding deposit of medium-scale sequence 6 , which contains the lower Virgula Member, and is consequently poorly developed (Strasser et al. 1999). According to Hardenbol et al. (1998), Kim $5_{\text {boreal }}$ is located in the Eudoxus ammonite zone, $380 \mathrm{ka}$ above Kim $4_{\text {boreal }}$. 


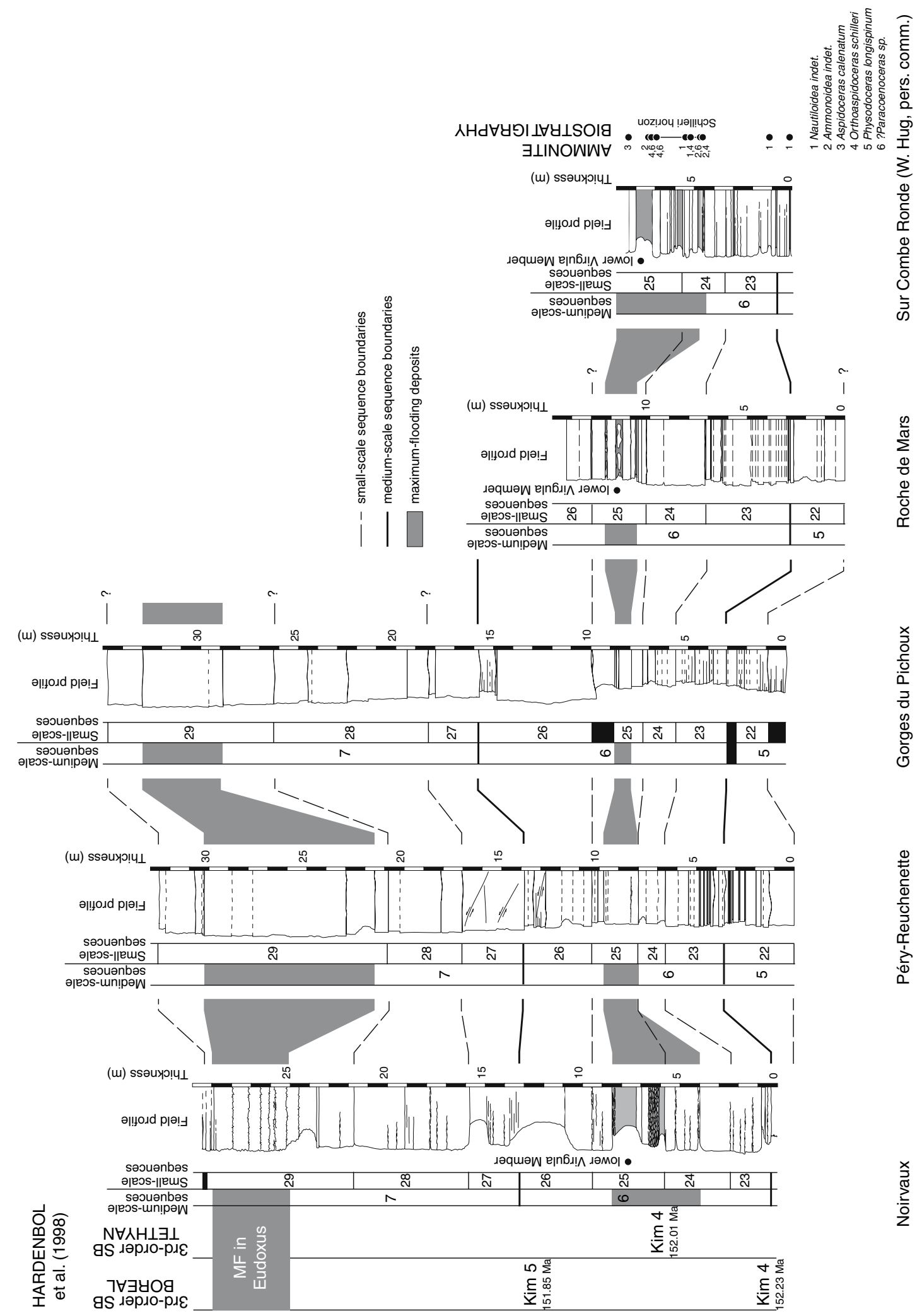

Fig. 10 High-resolution correlation of small- and medium-scale sequence boundaries between the Noirvaux, Péry-Reuchenette, Gorges du Pichoux, Roche de Mars, and Sur Combe Ronde sections and comparison with the Jurassic chronostratigraphic chart of Hardenbol et al. (1998). The studied interval is located in the lower part of the Late Kimmeridgian, close to the secondorder maximum-flooding of the Eudoxus ammonite zone 
This third-order sequence boundary is probably equivalent to the boundary between medium-scale sequences 6 and 7 defined in the studied sections. According to the correlation between the central Swiss Jura and Vocontian Basin sections (Colombié 2002; Colombié and Strasser 2003, 2005), this medium-scale sequence boundary would be located in the Eudoxus ammonite zone as well (Fig. 9).

Therefore, the comparison between the sequenceand cyclostratigraphic interpretation of the southern, central and northern Swiss Jura sections, the ammonite biostratigraphy defined in the Sur Combe Ronde section, and the chronostratigraphic chart of Hardenbol et al. (1998) shows that, in the Late Kimmeridgian of the Swiss Jura, medium-scale sequences (400 ka cycle) correlate with the third-order sequence boundaries defined by Hardenbol et al. (1998) for northern Europe. For the studied interval, the formation of the third-order sequences identified and dated by Hardenbol et al. (1998) in European basins is closely related to the $400 \mathrm{ka}$ eccentricity cycle of the Earth's orbit. Strasser et al. (2000) have already mentioned that for other Middle to Late Jurassic and Lower Cretaceous sections of Switzerland, France, Germany, and Spain.

\section{Correlation between Kimmeridgian sections of the Vocontian Basin, the Swiss Jura Mountains, southern England and northern France}

Williams et al. (2001) show that coarser grain layers characterize the Kimmeridge Clay Formation in Dorset and correlate with sandstone packages in the Boulonnais succession (Fig. 11). These packages are deposited at shallower depth than the underlying and overlying muddy units, and interpreted to approximate sequence boundaries. However, two problems appear in the correlation given by Williams et al. (2001) (Fig. 11): (1) in the Boulonnais section, the top of the second-order transgressive succession (or second-order maximum flooding or MF) is located in the lower part of the Autissiodorensis zone, while it occurs in the upper part of the Eudoxus zone in the Dorset section; (2) the sequence-stratigraphic interpretation for the Kimmeridge Clay Formation in Dorset differs from that previously made by Carolyn Williams in her Ph.D. thesis (Williams 2001).

The problem of correlating the top of the secondorder transgressive succession between the Kimmeridge Clay in Dorset and the Boulonnais succession could result, in one of the two sections or in both sections, from the definition of the boundary between the Eudoxus and the Autissiodorensis ammonite zones or from the definition of the second-order maximum flooding. Ammonites collected in the Boulonnais section place the Grès de Châtillon formation in the Contejeani subzone of the Eudoxus zone (Geyssant et al. 1993). The boundary between the Eudoxus and the Autissiodorensis zones is located at the top of the Grès de Châtillon (Williams 2001), just below the top of the second-order transgressive succession, which is actually located in the Autissiodorensis zone. The ammonite scheme applied to the Dorset section is based on Coe (1992) with further slight modification during extensive fieldwork (Morgans-Bell et al. 2001). While the resolution of ammonite stratigraphy in the Boulonnais succession is poor, the ammonite stratigraphy of the Kimmeridge Clay is of a much higher resolution and thus higher reliability (Williams 2001) and enables to place the top of the second-order transgressive succession in the Eudoxus ammonite zone. The first problem of correlation does probably not result from the definition of the boundary between the Eudoxus and the Autissiodorensis ammonite zones.

Using the grain size variation as a guide, Williams et al. (2001) interpret the Kimmeridge Clay Formation in Dorset in terms of sequence boundaries, transgressive surfaces, and maximum-flooding surfaces. Sequence boundaries correspond to abrupt increases in quartz content, transgressive surfaces, to abrupt decreases, and maximum-flooding surfaces coincide with the interval of finest grain sizes. Even if the sequencestratigraphic interpretation for the Kimmeridge Clay Formation produced by Williams et al. (2001) shows subtle difference from previous studies (Wignall 1991; Coe 1992; Partington et al. 1993; Melnyk et al. 1994; Ahmadi 1997; Taylor et al. 2001), there are no significant differences between the sequence-stratigraphic interpretation realised by Williams et al. (2001) for the Boulonnais succession and that made by Wignall (1991) and Proust et al. (1995). So, the sequence stratigraphic interpretation realised by Williams et al. (2001) for the Kimmeridge Clay Formation and the Boulonnais succession is solid. However, Williams (2001) shows that, even if it is usually possible to recognize intervals of high relative sea level in the Boulonnais section, in most cases it is not possible to delimit a well-defined surface as a maximum-flooding surface. This, in part, could explain the first correlation problem mentioned above.

The sequence-stratigraphic interpretation given by Williams (2001) for the Kimmeridge Clay Formation in Dorset is closer to that realised by Colombie and Strasser (2003) for the Kimmeridgian of the Swiss Jura and Vocontian basin than that made by Williams et al. (2001) for the Kimmeridge Clay Formation. So, 


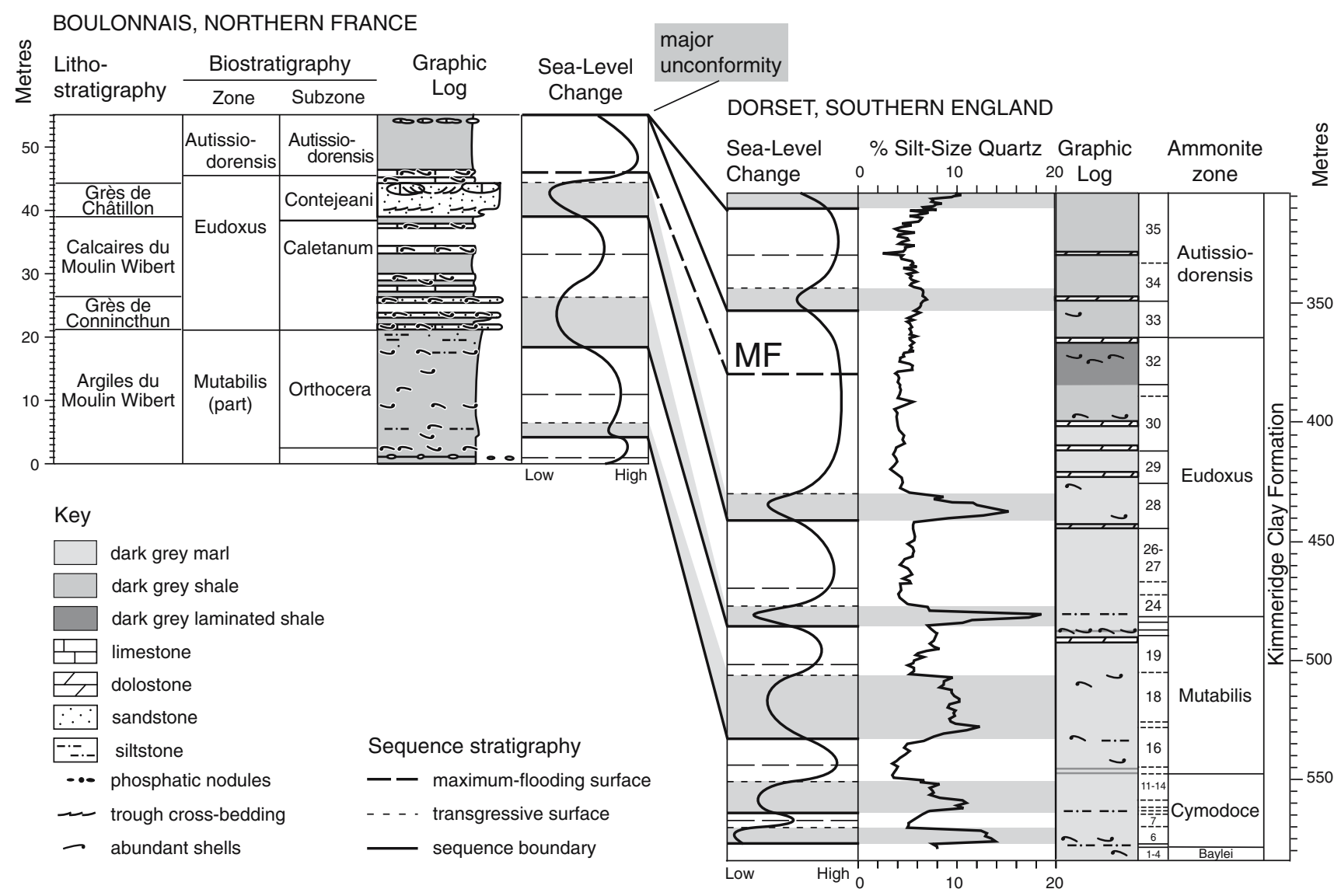

Fig. 11 Stratigraphic correlation between the Boulonnais succession in northern France and the lower part of the Kimmeridge Clay Formation in Dorset, modified from Williams (2001) and Williams et al. (2001)

the sequence-stratigraphic interpretation given by Williams (2001) for the Kimmeridge Clay Formation in Dorset is more suitable to construct a correlation between the Vocontian Basin, Swiss Jura, northern France and southern England. In the present paper, the sequence-stratigraphic interpretation of Williams et al. (2001) is consequently modified according to that of Williams (2001) (Fig. 11). In Williams (2001), the Autissiodorensis ammonite zone includes two sequence boundaries. The first one is located a third of the way up the Autissiodorensis zone and does not appear in Williams et al. (2001). This sequence boundary is characterised by a slight increase in silt-size quartz and would coincide with the unconformity located at the top of the Boulonnais succession. Indeed, Williams (2001) interprets the unconformity located at the top of the Boulonnais succession as an amalgamation of two lowstand erosion events, which probably correlate with the two sequence boundaries of the Autissiodorensis zone defined in Dorset.

According to the above modification, the Kimmeridge Clay contains seven sequence boundaries from the Cymodoce to the Autissiodorensis zone (Fig. 12).
Using ammonite biostratigraphy, these boundaries are correlated with the third-order sequence boundaries defined in northern Europe by Hardenbol et al. (1998). Two discrepancies appear. Firstly, the sequence boundary located in the lower part of the Mutabilis zone in Dorset does not have any equivalent in the stratigraphic chart. Secondly, Hardenbol et al. (1998) place the second-order maximum flooding in the Autissiodorensis zone whereas in Dorset it is located in the Eudoxus zone. Nevertheless, apart from these two differences, the sequence-stratigraphic interpretation given by Williams (2001) in Dorset is very similar to the sequence-stratigraphic framework proposed by Hardenbol et al. (1998) in northern Europe.

Using ammonite biostratigraphy, only five mediumscale sequence boundaries defined in the Swiss Jura and Vocontian Basin can be correlated with the thirdorder sequence boundaries proposed by Hardenbol et al. (1998) in southern Europe (Fig. 12). The others do not have any equivalent in the chart.

Based on the previous observations, a Tethyanto-boreal correlation is proposed (Fig. 12). In the 


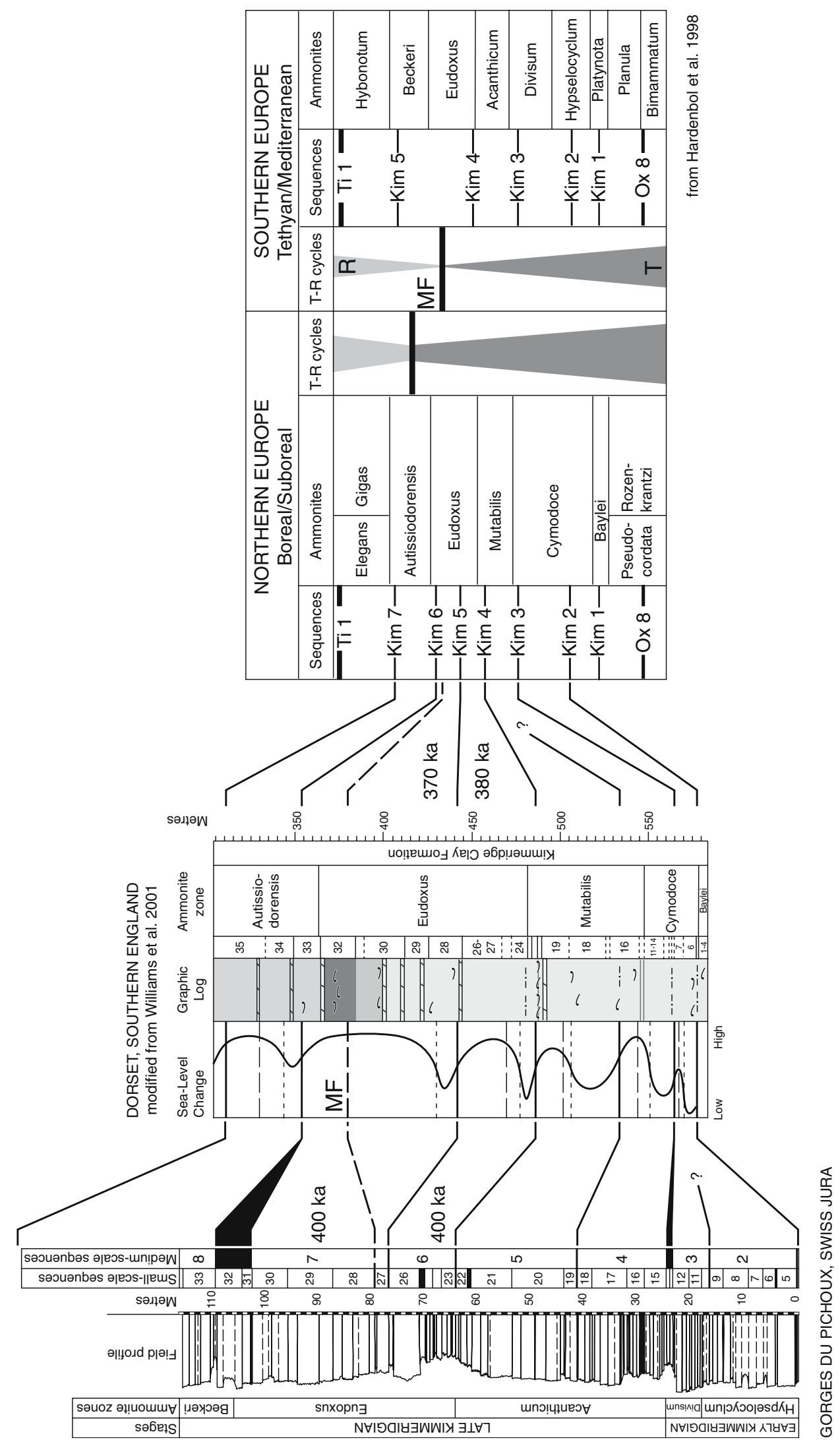

Fig. 12 High-resolution Tethyan-to-boreal correlation between the Swiss Jura, Vocontian Basin, and Wessex Basin in southern England. For discussion, refer to text 
chronostratigraphic chart of Hardenbol et al. (1998), Kim 2, Kim 3 and Kim 7 (respectively, Kim 5) correlate from the Tethyan to the boreal realms. Moreover, Kim 4 defined for northern Europe is located just below the boundary between the Mutabilis zone (equivalent to the Acanthicum zone in southern Europe) and the Eudoxus zone and is easy to identify. Furthermore, the duration between Kim 4 and Kim 5, and between Kim 5 and Kim 6 in northern Europe is close to $400 \mathrm{ka}$. Given the fact that the duration of a medium-scale sequence in the Swiss Jura is 400 ka (Colombie 2002; Colombié and Strasser 2003, 2005), the sequence boundaries at the top of medium-scale sequences 6 and 7 correspond probably to Kim 5 and Kim 6 defined by Hardenbol et al. (1998) in the boreal realm. Discrepancies appear that concern the sequence boundaries located at the top of medium-scale sequences 2 and 4 . The first one is defined neither in Dorset nor in the stratigraphic chart. The second one can be correlated from the Swiss Jura to Dorset, but does not appear in the chart. These discrepancies are probably due to frequent condensation in Early Kimmeridgian deposits that complicates sequence-stratigraphic interpretation. Finally, the second-order maximum flooding, which is recorded in the Eudoxus zone in the Swiss Jura, Vocontian Basin and Dorset, correlates with the end of the second-order transgression defined by Hardenbol et al. (1998) in southern Europe. Consequently, the sequence-stratigraphic interpretation given by Hardenbol et al. (1998) for northern Europe is relatively accurate and agrees with the stratigraphic framework defined in the Swiss Jura, which is, however, located in southern Europe. This confirms that the Late Kimmeridgian in the Jura Mountains displays boreal influences.

Some lithological markers support this correlation. In the Péry-Reuchenette and Gorges du Pichoux sections (central Swiss Jura), the sequence-boundary zone between medium-scale sequences 7 and 8 (Figs. 12,13) is thought to result at least partly from local or regional tectonics and would be located in the Beckeri zone (equivalent to the Autissiodorensis zone in the boreal realm) (Colombié 2002; Colombié and Strasser 2005). According to the Tethyan-to-boreal correlation proposed in the present paper, this interval corresponds to the unconformity that is defined at the top of the Boulonnais Kimmeridgian succession (Fig. 13). Moreover, a laterally extensive phosphatic nodule bed occurs $1.1 \mathrm{~m}$ from the base of the Boulonnais section (Williams 2001). The nodules are small (no more than $1.5 \mathrm{~cm}$ in diameter) and randomly oriented. This bed corresponds to a lithological change, with more bioturbated facies below the bed compared to above, and changes in geochemical and geophysical data sets. Below the phosphatic nodule bed, the spectral gammaray and total organic carbon (TOC) values are relatively high whilst directly after the bed they decrease rapidly. Williams et al. (2001) interpret this bed as a maximum-flooding surface (Figs. 11, 13). According to Baudin (personal communication), the same phosphatic nodule bed would be a bioturbated calcareous bed with quartz, glauconite, and phosphate grains and would coincide with the bed that occurs $45 \mathrm{~m}$ from the base of the borehole studied by Baudin et al. (2002) (i.e. $15 \mathrm{~m}$ in Fig. 13). In this borehole, the lower part of the Mutabilis zone is characterized by an organic-rich band that Baudin et al. (2002) interpret as the maximum-flooding surface above the sequence boundary equivalent to Kim 3 of Hardenbol et al. (1998) (Fig. 13). This organic-rich band occurs below the phosphatic nodule bed (Fig. 11, 13). In the northern Swiss Jura, the Banné Member, which is located in the Acanthicum zone (equivalent to the Mutabilis zone in the boreal realm), corresponds to the maximumflooding deposit of medium-scale sequence 4 or to the transgressive deposit of the second large-scale sequence (Fig. 8). This large-scale sequence coincides with the third-order sequence of Hardenbol et al. (1998) defined between Kim 3 and Kim 4 (Colombié 2002; Colombié and Strasser 2005). According to the Tethyan-to-boreal correlation proposed above, the Banné Member coincides probably with the organicrich band defined by Baudin et al. (2002), which would indicate the transgressive surface above Kim 3, and not the maximum-flooding surface as proposed by Baudin et al. (2002).

\section{Comparison between durations given by Weedon et al. (2004), Hardenbol et al. (1998), and this work}

Weedon et al. (2004) used magnetic susceptibility, photoelectric factor, and total gamma-ray data from the type Kimmeridge Clay Formation in Dorset (southern England) in order to identify sedimentary cycles. Cycles are expressed as large-amplitude cycles of 1.87-4.05 m wavelength and smaller-amplitude cycles of around half that wavelength. The average period for the longer wavelength cycles results from subdividing the estimated duration of the Kimmeridgian [as based on the Gradstein et al. (1995) and Pálfy et al. (2000) timescales] by the number of cycles contained in this interval. It appears that the longer wavelength cycles correspond to records of orbital obliquity (i.e. $38 \mathrm{ka}$ in the Late Jurassic). Assuming that the longer wavelength cycles record obliquity 
Fig. 13 Lithological markers in the Gorges du Pichoux section, Cap de la Crèche outcrop, and borehole $4 \mathrm{HS}$ 65 , that support the Tethyanto-boreal correlation given in the present work

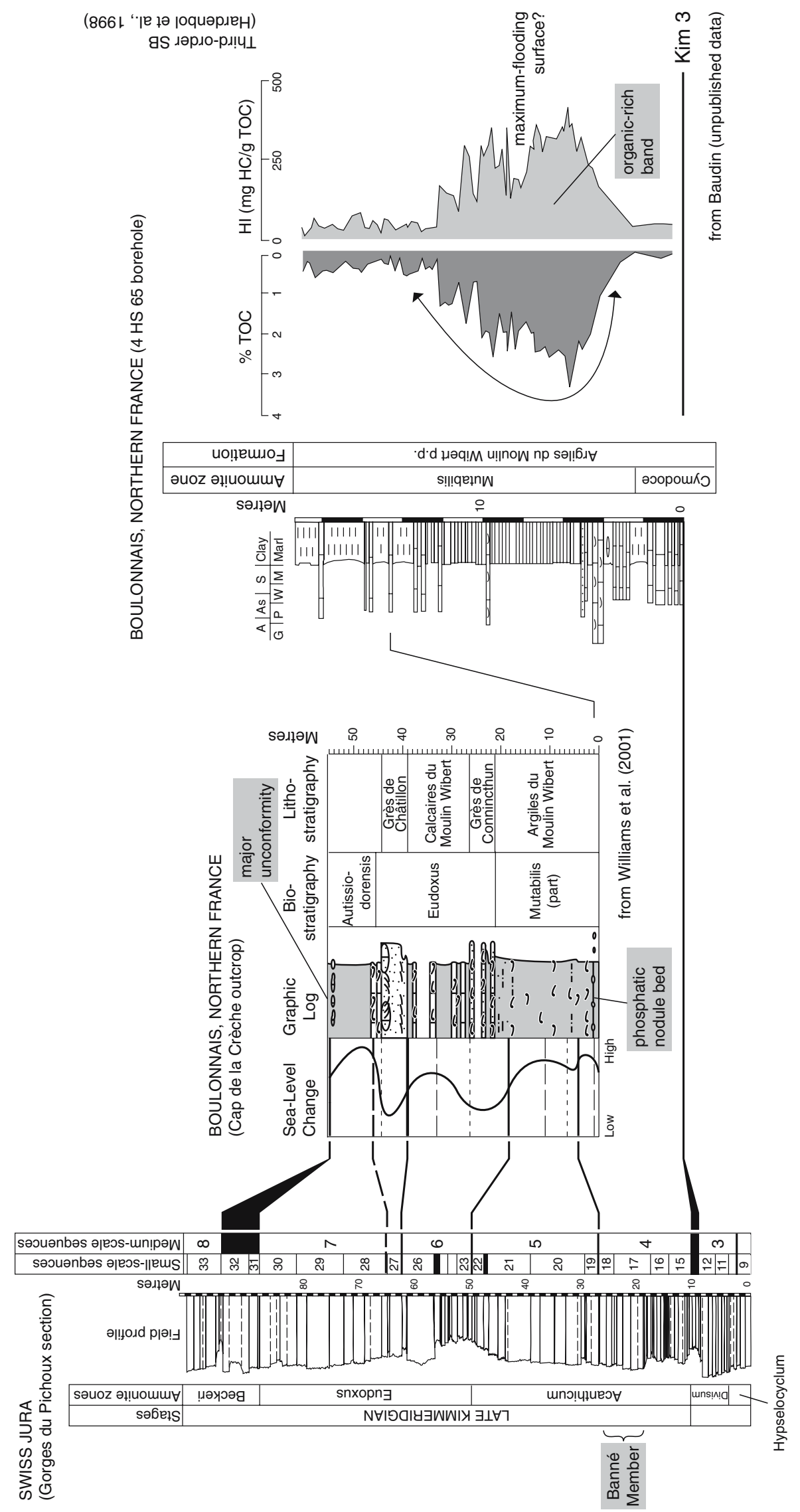


variations, the average signal was orbitally tuned by (1) fixing the time interval between successive cycles at $38 \mathrm{ka}$, and (2) plotting data between cycle boundaries as though sedimentation rates were constant within each cycle. Because of the possibility of undetected stratigraphic gaps, and thus potentially missing cycles, orbital tuning provides minimum durations of ammonite zones. Nevertheless, this spectral analysis based cyclostratigraphy can be compared to the cyclostratigraphic interpretation given in the present work, which results from field observations, and to the durations estimated by Hardenbol et al. (1998) (Fig. 14).

Assuming that medium-scale sequences defined in the Kimmeridgian of the Swiss Jura and Vocontian Basin represent a duration of $400 \mathrm{ka}$, the time span between the medium-scale sequence boundaries equivalent to Kim 3 and Kim 4 defined by Hardenbol et al. (1998) in northern Europe would be $0.8 \mathrm{Ma}$ (Fig. 14). For the same time interval, Hardenbol et al. (1998) give duration of $0.51 \mathrm{Ma}$. This interval corresponds approximately to the Mutabilis ammonite zone, the minimum duration of which was calculated at $0.745 \mathrm{Ma}$ by Weedon et al. 2004. The duration given by Weedon et al. (2004) for the lower part of the studied interval is therefore comparable to that estimated in the present work.

The duration of the time interval between Kim 4 and Kim 6 defined by Hardenbol et al. (1998) in northern Europe is about $0.8 \mathrm{Ma}$. The same time interval in the Swiss Jura and the Vocontian Basin includes two medium-scale sequences that correspond to $0.8 \mathrm{Ma}$ as well. This interval coincides approximately with the Eudoxus ammonite zone whose minimum duration was calculated to be $1.486 \mathrm{Ma}$ by Weedon et al. (2004) (Fig. 14). The duration given by Weedon et al. (2004) is consequently much longer than the two first.
The time interval between Kim 6 and Kim 7 defined in northern Europe by Hardenbol et al. (1998) contains in the Swiss Jura two medium-scale sequences that correspond to $0.8 \mathrm{Ma}$. Hardenbol et al. (1998) give $0.620 \mathrm{Ma}$ for the same interval. It corresponds approximately to the Autissiodorensis ammonite zone whose minimum duration is $1.062 \mathrm{Ma}$ according to Weedon et al. (2004). The duration of the upper part of the studied interval estimated in this work is intermediate between the duration given by Hardenbol et al. (1998) and Weedon et al. (2004) (Fig. 14).

\section{Discussion}

There are various possible explanations for the differences between the durations estimated by Weedon et al. (2004), Hardenbol et al. (1998), and this work (Fig. 14). However, none of them is unambiguous.

The main drawback of the chart of Hardenbol et al. (1998) is that it represents a compilation of data of which the source remains unknown. Consequently, it can only be used "as is" and confirmed or questioned by comparing it with regional datasets. Previous work in the Swiss and French Jura Mountains (Strasser and Hillgärtner 1998; Hillgärtner 1999; Colombié 2002; Hug 2003; Colombié and Strasser 2005; Rameil 2005) has shown that, despite minor deviation in selected intervals, the overall timing given by the chart is confirmed by cyclostratigraphy.

Comparing the results of Weedon et al. (2004) with the cyclostratigraphic interpretation presented in this paper, there are two basic hypotheses: either (1) there was no orbital signal recorded in the two localities at all, or (2) the sedimentary record of one of the compared regions is incomplete or consists of too many sedimentary cycles, respectively. Hypothesis (1) can be ruled out as Weedon et al. (2004) demonstrate
Fig. 14 Comparison between minimum durations of ammonite zones and time spans between third-order and medium-scale sequence boundaries as given by Weedon et al. (2004) in southern England, Hardenbol et al. (1998) in northern and southern Europe, and in this work for the Swiss Jura and the Vocontian Basin sections, respectively. Durations and ages of third-order sequence boundaries are given in $\mathrm{Ma}$

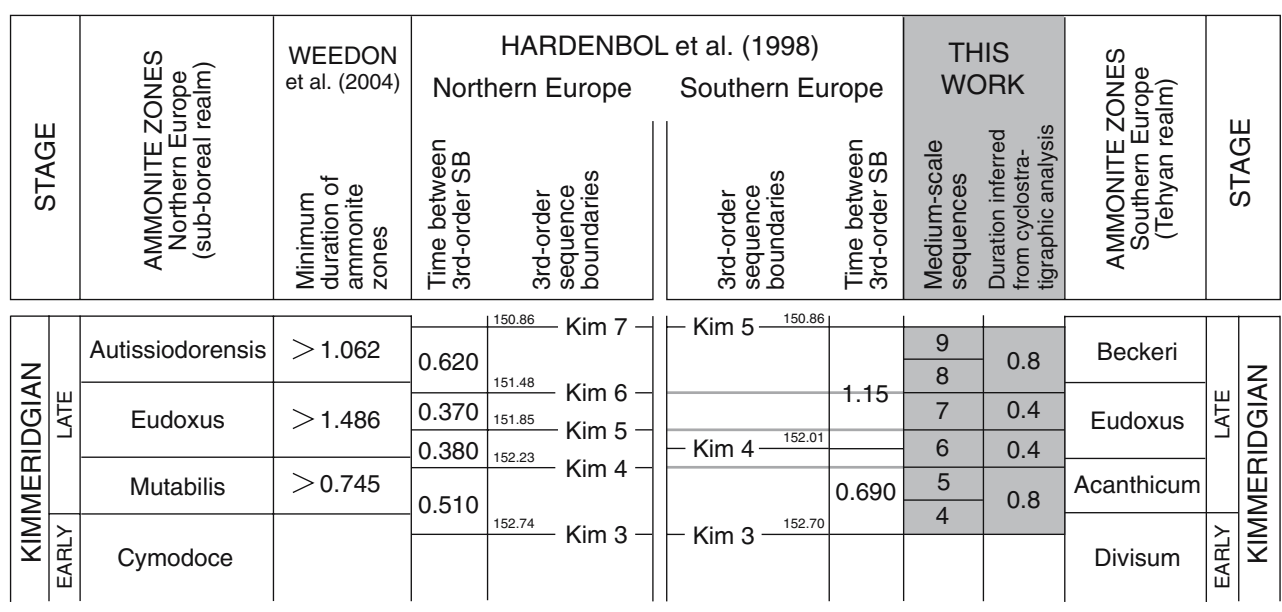


precession and obliquity forcing and also evidence for the short eccentricity signal in their dataset. There also is strong evidence for orbital forcing in the Late Jurassic of the Jura Mountains (Colombié 2002; Colombié and Strasser 2005; Rameil 2005). Consequently, hypothesis (2) is preferred here.

\section{Biostratigraphy}

Weedon et al. (2004) link their cyclostratigraphic interpretation to the boreal ammonite zonation, whereas this study relates the developed time frame to third-order sequence boundaries (Fig. 14). Thus, the problems of exactly linking sequence stratigraphic schemes to biostratigraphy, as well as the difficulty to correlate between the boreal and Tethyan ammonite zonal scheme may add to the observed discrepancies. For example, it is very likely that the Baylei, Cymodoce and Mutabilis ammonite zones of the type Kimmeridge Clay Formation are incomplete. Also, there are possible errors associated with the definition of the zones in the type section, and, to the present day, there is no proof of isochroneity of Late Jurassic ammonite zones (Weedon et al. 2004). However, this does not explain the considerable discrepancies between Weedon et al. (2004) and the chart of Hardenbol et al. (1998) (Fig. 14).

\section{Tectonic setting and depositional bias}

From Late Jurassic to Palaeocene time, the palaeogeography of northwest European epicratonic platform was controlled by the Atlantic regime and the northward propagation of the North Atlantic rift (Ziegler 1989; Ziegler and van Horn 1989). This major plate reorganisation was associated with variations in the oceanic spreading rates and intraplate stresses (Cloething 1986, 1988a, b; Karner 1986; Lambeck et al. 1987) giving rise to doming, subsidence and break up in the adjacent North Sea (Ziegler and van Horn 1989), and reactivations of ancient fractures over the whole incipient North Atlantic margin.

In southern England, the extensional tectonics led to the development of $\mathrm{W}-\mathrm{E}$ trending half-grabens, resulting in block tilting and thus markedly different thicknesses of the Kimmeridge Clay depending on footwall or hanging wall position (Chadwick 1986; Newell 2000; Morgans-Bell et al. 2001). Within such an environment defined by high tectonic activity, it has to be considered that processes such as erosion, sediment redistribution, and frequent changes in subsidence rate may be triggered which can distort the recording of an existing orbital signal (tectonic forcing). As Weedon et al. (2004) draw their cyclostratigraphic interpreta- tion from only one (composite) type section (cf. Morgans-Bell et al. 2001), it would be of interest to know if other sections in different (structural) positions furnish exactly the same results as the examined type section. In comparison to southern England, the Jura platform experienced a relatively homogenous subsidence during the Late Jurassic.

In contrast to the basinal environments of the Kimmeridge Clay Formation, the Jura platform was characterised by shoalwater conditions and was thus subject to repeated emersions that can potentially result in "missed beats" (Goldhammer et al. 1990). However, no major hiatuses have been detected in the Swiss Jura sections. This is in accordance with the general transgressive trend and greenhouse conditions during the Kimmeridgian: low amplitudes of highfrequency sea-level fluctuations could not create deep erosion. Moreover, carbonate production and accumulation were sufficient to constantly fill the created accommodation space and the studied sections are essentially composed of low-energy lagoonal deposits, in which lateral facies changes are reduced. Lastly, autocyclicity can be excluded as the cyclic stacking pattern can be correlated between several sections (Colombié 2002; Colombié and Strasser 2005; Rameil 2005) and over many tens of km (Fig. 3). The Kimmeridgian of the Swiss Jura is therefore well suited for cyclostratigraphic interpretation based on field observations (Colombié 2002; Colombié and Strasser 2005).

Notably, the stacking pattern of depositional sequences between the medium-scale sequence boundaries equivalent to Kim 3 and Kim 4 of Hardenbol et al. (1998) in the Swiss Jura shows one medium- for four small-scale sequences. This ratio clearly suggests an orbital control on sedimentation. Above Kim 4, however, homogenous facies and local or regional tectonics make the sequence stratigraphic interpretation and the correlation with other western European basins more difficult (Colombié 2002; Colombié and Strasser 2005).

With the evolution of sequence stratigraphic concepts, it became clear that carbonate and siliciclastic sedimentary systems react different to sea-level changes (e.g. Posamentier and Vail 1988; Handford and Loucks 1993; "depositional bias" of Schlager 2005). This of course holds also true for the high-frequency, low-amplitude sea-level changes that result from orbital forcing in the Late Jurassic Greenhouse world. Taking also into account the differing palaeogeographic positions (Jura Mountains: platform top-southern England: basin floor), and considering that, due to local outcrop conditions and rock properties, completely different parameters were chosen to define sedimentary 
sequences or "cycles" (cf. Materials and methods of this paper and Weedon et al. 2004), it is possible that the two sedimentary systems react completely different to orbital forcing. In this context, it is also interesting to note that in southern England the obliquity cycle (38 ka) is dominant and there is no evidence for direct eccentricity forcing at the 100 and $400 \mathrm{ka}$ periods (Weedon et al. 2004). In contrast, eccentricity forcing is interpreted to be the main driver for the generation of small- and medium-scale sedimentary sequences in the Jura Mountains (Colombié 2002; Colombié and Strasser 2005; Rameil 2005).

Cyclostratigraphic interpretation of different sedimentary successions bounded by correlative conformities and lacking significant hiatuses should theoretically result in the same inferred duration. The presented data show, however, that this is not always the case and that the combination of biostratigraphic problems, different tectonic settings, and depositional bias may produce contradicting results from what appear to be orbitally forced successions. Consequently, more emphasis should be placed on understanding these factors, specifically the latter two.

For the two discussed cyclostratigraphic time frames (Fig. 14) this implies that it remains unclear which one of the two is correct. First comparisons of the Kimmeridgian cycle record in the Jura Mountains with its equivalent in NE-Spain have shown that inferred durations seem to be comparable within the Tethyan realm and that local tectonics may indeed alter the cycle record (Bádenas et al. 2003). However, further research, and specifically more data from the boreal domain, is needed in order to solve this open question.

\section{Conclusions}

A sedimentological and high-resolution sequencestratigraphic interpretation has been presented for the Cras d'Hermont and Roche de Mars sections (northern Swiss Jura) that contain subboreal and submediterranean ammonites and constitute a good relay in a Tethyan-to-boreal correlation. The Cras d'Hermont and Roche de Mars sections are mainly composed of mudstones and bioclast-peloid wackestones to packstones that are representative of sheltered to semirestricted lagoons. Variations in bed thicknesses, discontinuities (such as firmgrounds and hardgrounds), changes in texture and bioclast diversity, and evolution through time of depositional environments has led to the definition of medium- and small-scale sequences, which are found to be organised in a hierarchical stacking pattern.
According to lithological markers, the Cras d'Hermont and Roche de Mars sections are correlated with central (Gorges du Pichoux and Péry-Reuchenette), southern (Noirvaux) Swiss Jura and Vocontian Basin sections, where a sequence- and cyclostratigraphic framework has been defined. According to this correlation, the Banné Member that occurs in the upper part of the Cras d'Hermont section coincides in the Gorges du Pichoux section with argillaceous limestones that contain a lot of brachiopods and precede a sudden increase in bed thicknesses. The lower Virgula Member, which occurs in the Noirvaux section and in the upper part of the Roche de Mars section, corresponds in the central Swiss Jura sections to increasing bioclast diversity and bed thickness. Linking the highresolution correlation between southern, central, and northern Swiss Jura sections with the ammonite biostratigraphy defined in the Sur Combe Ronde section (Marty 2002; Marty et al. 2003) and comparing it with the chronostratigraphic chart of Hardenbol et al. (1998) reveals that the sequence boundary between medium-scale sequences 5 and 6 is located at the top of the Mutabilis ammonite zone (below the Schilleri horizon) and corresponds probably to Kim 4 defined by Hardenbol et al. (1998) for northern Europe (Kim $\left.4_{\text {boreal }}\right)$. In all studied sections, Kim 4 for southern Europe (Kim $4_{\text {Tethyan }}$ ) is located at the top of mediumscale sequence 24 , two small-scale sequences (or $200 \mathrm{ka})$ below the boundary between medium-scale sequences 5 and 6 that corresponds to Kim $4_{\text {boreal }}$. Kim $4_{\text {Tethyan }}$ is included in the maximum-flooding deposit of medium-scale sequence 6 (that contains the lower Virgula Member) and is consequently poorly developed. This result shows that in the Late Kimmeridgian of the Swiss Jura medium-scale sequences (400 ka cycle) correlate with the third-order sequence boundaries identified in northern Europe by Hardenbol et al. (1998).

A long-distance transect between the Vocontian Basin, the Swiss Jura, and the Wessex-Weald Basin in northern France and southern England has been constructed, using the correlation proposed by Williams et al. (2001) between the deep-water Dorset section and the coeval mixed offshore and littoral deposits of Boulonnais. This correlation shows that third-order depositional sequences, and also higherfrequency sequences, correlate from the Tethyan to the boreal realm and that the sequence stratigraphic interpretation given by Hardenbol et al. (1998) for northern Europe is in tune with the sequence stratigraphic framework established in the Swiss Jura. High-resolution sequence stratigraphy provides a valuable tool to correlate between northern and 
southern Europe. Nevertheless, the comparison between the (cyclostratigraphic) durations estimated by Hardenbol et al. (1998), by Weedon et al. (2004), and in this work is not evident. Possible explanations why cyclostratigraphic analysis leads to different results in these areas are ongoing difficulties in the exact correlation of Tethyan and boreal ammonite zones, the different tectonic settings of southern England and Switzerland during the Late Jurassic, and/or the differing reaction of contrasting sedimentary systems (deeper-water siliciclastic basin versus shallow-water carbonate platform) to orbital forcing.

Acknowledgments This study results from a year of postdoctoral research of Claude Colombie at the Earth Sciences department of the University of Oxford, which was financially supported by the Swiss National Science Foundation (Project No 81FR-68839). Claude Colombié gratefully acknowledges Stephen Hesselbo for receiving her in Oxford and sharing his precious time for paper reviews and discussions. We thank Helen Morgans-Bell for useful information on the Kimmeridge Clay Formation of southern England, and François Baudin for providing unpublished data from the Kimmeridgian of the Boulonnais. We also thank the Section de Paléontologie in Porrentruy, Switzerland, and particularly Wolfgang Hug, for deliberately sharing some essential information. Stephen, François, and Fabienne Giraud from the UMR CNRS 5125 of the University of Lyon 1 and Adrian Immenhauser from the Ruhr-University Bochum gave many helpful comments. Andrea Cozzi and Helmut Weissert provided constructive reviews. They all greatly helped to improve earlier versions of the manuscript. And last, but not least, a warm "thank you" goes to André Strasser for everything we were allowed to learn and experience during the years as his Ph.D. students.

\section{References}

Abbink O, Targarona J, Brinkhuis H, Visscher H (2001) Late Jurassic to earliest Cretaceous palaeoclimatic evolution of the southern North Sea. Glob Planet Change 30:231-256

Ahmadi ZM (1997) Sequence stratigraphy using wireline logs from the Upper Jurassic of England. Unpublished doctoral dissertation, University of Durham, Great Britain

Atrops F, Gygi R, Matyja BA, Wierzbowski A (1993) The Amoeboceras faunas in the middle Oxfordian-lowermost Kimmeridgian, submediterranean succession, and their correlation value. Acta Geol Pol 43:213-227

Aubert D (1932) Un niveau à Exogyra virgula, Defr. à la Vallée de Joux. Bull Soc Vaud Sc Nat 57:477-478

Aubert D (1950) Nouvelles observations sur le niveau à Exogyra virgula dans le Jura. Bulletin des Laboratoires de Géologie, Minéralogie, Géophysique et du Musée géologique de l'Université de Lausanne 95:1-6

Bádenas B, Aurell M, Rodríguez-Tovar FJ, Pardo-Igúzquiza E (2003) Sequence stratigraphy and bedding rhythms of an outer ramp limestone succession (Late Kimmeridgian, Northeast Spain). Sedment Geol 161:153-174

Baudin F, Deconinck JF, Gardin S, Hantzpergue P, Jan du Chêne R, Schnyder J, Vidier JP (2002) Stratigraphie intégrée du Kimméridgien inférieur du Boulonnais et de
Normandie (France). Comparaison avec les stratotypiques du Dorset $(\mathrm{GB})$. Abstr $3^{\text {ème }}$ Congrès français de Stratigraphie, Lyon, France, vol 32

Chadwick RA (1986) Extension tectonics in the Wessex Basin, southern England. J Geol Soc London 143:465-488

Cloething S (1986) Intraplate stresses: a new tectonic mechanism for fluctuations of relative sea-level. Geology 14:617-620

Cloething S (1988a) Intraplate stresses: a new element in basin analysis. In: Kleinspehn KL, Paola C (eds) New perspectives in basin analysis. Frontiers in sedimentary geology. Springer, Berlin Heidelberg New York, pp 205-230

Cloething S (1988b) Intraplate stresses: a tectonic causes for third-order cycles in apparent sea-level? In: Wilgus CK, Hastings BS, Posamentier H, van Wagoner J, Ross CA, Kendall C (eds) Sea-level change-an integrated approach. Spec Publ Soc Econ Petrol Mineral 42:19-29

Coe AL (1992) Unconformities within the Upper Jurassic of the Wessex Basin, southern England. Unpublished doctoral dissertation, University of Oxford, Great Britain

Collier REL, Dart CS (1991) Neogene to quaternary rifting, sedimentation and uplift in the Corinth Basin, Greece. J Geol Soc London 148:1049-1065

Colombié C (2002) Sédimentologie, stratigraphie séquentielle et cyclostratigraphie du Kimméridgien du Jura suisse et du Bassin vocontien (France): relations plate-forme-bassin et facteurs déterminants. GeoFocus 5, Fribourg, pp 1-201

Colombié C, Strasser A (2003) Depositional sequences in the Kimmeridgian of the Vocontian Basin (France) controlled by carbonate export from shallow-water platforms. Geobios 36:675-683

Colombié C, Strasser A (2005) Facies, cycles, and controls on the evolution of a keep-up carbonate platform (Kimmeridgian, Swiss Jura). Sedimentology 52:1207-1227

Colombié C, Hug WA, Mora R, Rameil N, Strasser A (2004) High-resolution correlations in peritidal environments of the Jura Mountains' Upper Kimmeridgian using a multidisciplinary approach. Abstr 12th Meeting of Swiss Sedimentologists, Fribourg, Switzerland:16-17

Dauwalder P, Remane J (1979) Etude du banc à Nérinées à la limite "Kimméridgien-Portlandien" dans le Jura Neuchâtelois méridional. Paläont Z 53:163-181

Enay R, Contini D, Boullier A (1988) Le Séquanien-type de Franche-Comté (Oxfordien supérieur): datations et corrélations nouvelles, conséquences sur la paléogéographie et l'évolution du Jura et régions voisines. Eclogae geol Helv 81:295-363

Geyssant JR, Vidier JP, Herbin JP, Proust JN, Deconinck JF (1993) Biostratigraphie et paléoenvironnement des couches de passage Kimméridgien/Tithonien du Boulonnais (Pas-deCalais): nouvelles données paléontologiques (ammonites), organisation séquentielle et contenu en matière organique. Géologie de la France 4:11-24

Ginsburg RN (1971) Landward movement of carbonate mud: new model for regressive cycles in carbonates. Am Assoc Pet Geol Bull 55:340

Goldhammer RK, Dunn PA, Hardie LA (1990) Depositional cycles, composite sea-level changes, cycle stacking patterns, and the hierarchy of stratigraphic forcing: examples from Alpine Triassic platform carbonates. Geol Soc Am Bull 102:535-562

Gradstein FM, Agterberg FP, Ogg JG, Hardenbol J, Van Veen P, Thierry J, Huang Z (1994) A Mesozoic time scale. J Geophys Res 99:24051-24074

Gradstein FM, Agterberg FP, Ogg JG, Hardenbol J, Van Veen P, Thierry J, Huang Z (1995) A Triassic, Jurassic, and Cretaceous time scale. In: Berggren WA, Kent DV, Aubry M.-P, 
Hardenbol J (eds) Geochronology, time scales and gloabal stratigraphic correlation. SEPM Spec Publ 54:95-126

Gygi RA (1995) Datierung von Seichtwassersedimenten des Späten Jura in der Nordwestschweiz mit Ammoniten. Eclogae Geol Helv 88:1-58

Gygi RA (2000) Integrated stratigraphy of the Oxfordian and Kimmeridgian (Late Jurassic) in northern Switzerland and adjacent southern Germany. Mem Swiss Academy of Sciences 104, Birkhäuser Verlag, pp 1-151

Handford CR, Loucks RG (1993) Carbonate depositional sequences and system tracts-responses of carbonate platforms to relative sea-level changes. In: Loucks RG, Sarg JF (eds) Carbonate sequence stratigraphy: recent developments and applications. AAPG Mem 57:3-41

Hardenbol J, Thierry J, Farley MB, Jacquin T, de Graciansky PC, Vail PR (1998) Jurassic chronostratigraphy. In: de Graciansky PC, Hardenbol J, Jacquin T, Vail PR (eds) Mesozoic and cenozoic sequence stratigraphy of european basins. SEPM Spec Publ 60 (chart)

Hillgärtner H (1999) The evolution of the French Jura platform during the Late Berriasian to Early Valanginian: controlling factors and timing. GeoFocus 1, Fribourg, pp 1-203

Hug W (2003) Sequenzielle Faziesentwicklung der Karbonatplattform des Schweizer Jura im Späten Oxford und frühesten Kimmeridge. GeoFocus 7, Fribourg, pp 1-155

Karner GD (1986) Effects of lithospheric in-plane stress on sedimentary basin stratigraphy. Tectonics 5:573-588

Lambeck K, Cloething S, McQueen H (1987) Intraplate stresses and apparent changes in sea level: the basins of northwestern Europe. In: Tankard AJ (ed). Sedimentary basins and basin forming machanisms. C S G Mem 12:259-268

Macquaker JHS, Gawthorpe KG, Taylor KG, Oates MJ (1998) Heterogeneity, stacking patterns and sequence stratigraphy in distal mudstone successions; examples from the Kimmeridge Clay Formation, UK. In: Schieber J, Zimmerle W, Sethi P (eds) Recent progress in shale research. Schweizerbart'sche Verlagsbuchhandlung, Stuttgart, pp 163-186

Marty D (2002) Le Secondaire (Mésozoïque) du Jura le long de la Transjurane avec recherche approfondie sur le site de Courtedoux-Sur Combe Ronde. In: Section de Paléontologie (ed). Rapport d'activités 2002, Paléontologie et transjurane 3. Rapport de l'Office Cantonal de la Culture, Section de Paléontologie, Porrentruy, Switzerland, pp 1-52

Marty D, Diedrich C (2001) Fouilles paléontologiques dans les unités du Secondaire (Mésozoïque): Combe de Vâ-tcheTchâ, Déblais du Tunnel du Banné. In: Section de Paléontologie (ed). Rapport d'activités 2001, Paléontologie et transjurane 2. Rapport de l'Office Cantonal de la Culture, Section de Paléontologie, Porrentruy, Switzerland, pp 1-52

Marty D, Hug WA, Iberg A, Cavin L, Meyer CA, Lockley MG (2003) Preliminary report on the Courtedoux dinosaur tracksite from the Kimmeridgian of Switzerland. Ichnos 10:209-219

Melnyk DH, Smith DG, Amiri-Garroussi K (1994) Filtering and frequency mapping as tools in subsurface cyclostratigraphy, with examples from the Wessex Basin, UK. In: de Boer PL, Smith DG (eds) Orbital forcing and cyclic sequences. IAS Spec Publ 19:13-46

Meyer CA (1994) A new sauropods printsite from the Upper Jurassic of northern Switzerland ("Kimmeridgian"; Montbautier, Kt. Bern) by $\mathrm{Ph}$. Mouchet-a reply. Revue de Paléobiologie 13:427-428

Meyer M (2000) Le complexe récifal kimméridgien-tithonien du Jura méridional interne (France), évolution multifactorielle, stratigraphie et tectonique. Terre \& Environnements 24, Genève, pp 1-179
Morgans-Bell HS, Coe AL, Hesselbo SP, Jenkyns HC, Weedon GP, Marshall JEA, Tyson RV, Williams CJ (2001) Integrated stratigraphy of the Kimmeridge Clay Formation (Upper Jurassic) based on exposures and boreholes in south Dorset, UK. Geol Mag 138:511-539

Newell AJ (2000) Fault activity and sedimentation in a marine rift basin (Upper Jurassic, Wessex Basin, UK). J Geol Soc London 157:83-92

Pálfy J, Smith PL, Mortensen JK (2000) A U-Pb and ${ }^{40} \mathrm{Ar}-{ }^{39} \mathrm{Ar}$ time scale for the Jurassic. Can J Earth Sci 37:923-944

Partington MA, Mitchener BC, Milton NJ, Fraser AJ (1993) Genetic sequence stratigraphy for the North Sea Late Jurassic and Early Cretaceous: distribution and prediction of Kimmeridgian-Late Ryazanian in the North Sea and adjacent areas. In: Parker JR (ed). Petroleum geology of northwest Europe. Proceedings of the 4th Conference, Gelogical Society, London, 347-370

Pasquier JB, Strasser A (1997) Platform-to-basin correlation by high-resolution sequence stratigraphy and cyclostratigraphy (Berriasian, Switzerland and France). Sedimentology 44:1071-1092

Pittet B, Strasser A (1998) Depositional sequences in deep-shelf environments formed through carbonate-mud import from the shallow platform (Late Oxfordian, German Swabian Alb and eastern Swiss Jura). Eclogae geol Helv 91:149-169

Posamentier HW, Vail PR (1988) Eustatic controls on clastic deposition II-sequence and system tract models. In: Wilgus CK, Hastings BS, Posamentier H, Van Wagoner J, Ross CA, Kendall CGStC (eds) Sea-level changes: an integrated approach. SEPM Spec Publ 42:125-154

Pratt BR, James NP (1986) The Saint George Group (Lower Ordovician) of western Newfoundland: tidal flat island model for carbonate sedimentation in shallow epeiric seas. Sedimentology 33:313-343

Proust JN, Deconinck JF, Geyssant JR, Herbin JP, Vidier JP (1995) Sequence analytical approach to the upper Kimmeridgianlower Tithonian storm-dominated ramp deposits of the Boulonnais (northern France). A landward time-equivalent to offshore marine source rocks. Geol Rundsch 84:255-271

Rameil N (2005) Carbonate sedimentology, sequence stratigraphy, and cyclostratigraphy of the Tithonian in the Swiss and French Jura Mountains: a high-resolution record of changes in sea level and climate. GeoFocus 13, Fribourg, pp 1-246

Ravnås R, Nøttvedt A, Steel RJ, Windelstad J (2000) Syn-rift sedimentary architecture $s$ in the northern North Sea. In: Nøttvedt A (ed) Dynamics of the Norwegian Margin. Spec Publ Geol Soc London167, pp 133-177

Schlager W. (2005) Carbonate sedimentology and sequence stratigraphy. SEPM Concepts in Sedimentology and Paleontology 8, pp 1-200

Schweigert G, Callomon JH (1997) Der bauhini-Faunenhorizont und seine Bedeutung für die Korrelation zwischen tethyalem un subborealem Oberjura. Stuttgarter Beitrage zur Naturkunde Serie B (Geologie und Palaontologie) 247:1-69

Section de paléontologie (2001) Rapport 2000: premières activités. Paléontologie et Transjurane 1. Rapport de l'Office Cantonal de la Culture, Section de Paléontologie, Porrentruy, Switzerland

Strasser A (1984) Black-pebble occurrence and genesis in Holocene carbonate sediments (Florida Keys, Bahamas, and Tunisia). J Sediment Petrol 54:1097-1109

Strasser A (1991) Lagoonal-peritidal sequences in carbonate environments: autocyclic and allocyclic processes. In: Einsele G, Ricken W, Seilacher A (eds) Cycles and events in stratigraphy. Springer, Berlin Heidelberg New York, pp 709-721 
Strasser A (1994) Milankovitch cyclicity and high-resolution sequence stratigraphy in lagoonal-peritidal carbonates (Upper Tithonian-Lower Berriasian, French Jura Mountains). In: De Boer PL, Smith DG (eds) Orbital forcing and cyclic sequences. IAS Spec Publ 19:285-301

Strasser A, Davaud E (1983) Black pebbles of the Purbeckian (Swiss and French Jura): lithology, geochemistry and origin. Eclogae geol Helv 76:551-580

Strasser A, Hillgärtner H (1998) High-frequency sea-level fluctuations recorded on a shallow carbonate platform (Berriasian and Lower Valanginian of Mount Salève, French Jura). Eclogae Geol Helv 91:375-390

Strasser A, Pittet B, Hillgärtner H, Pasquier JB (1999) Depositional sequences in shallow carbonate-dominated sedimentary systems: concepts for a high-resolution analysis. Sedment Geol 128:201-221

Strasser A, Hillgärtner H, Hug W, Pittet B (2000) Third-order depositional sequences reflecting Milankovitch cyclicity. Terra Nova 12:303-311

Taylor SP, Sellwood BW, Gallois RW, Chambers MH (2001) A sequence stratigraphy of the Kimmeridgian and Bolonian stages (late Jurassic): Wessex-Weald Basin, southern England. J Geol Soc London 158:179-192

Thalmann HK (1966) Zur Stratigraphie des oberen Malm im südlichen Berner und Solothurner Jura. Mitt natf Ges Solothurn 22:4-25

Thierry J (1999) The Jurassic biochronostratigraphy and sequence chronostratigraphy charts. ISJS Newslett 27:13-16

Thierry J et al. (41 co-authors) (2000) Early Kimmeridgian. In: Dercourt M, Gaetani M, Vrielynck B, Barrier E, Biju-Duval B, Brunet MF, Cadet JP, Crasquin S, Sandulescu M (eds) Atlas Peri-Tethys, Palaeogeographical maps. CCGM/ CGMW, Paris, map 10
Vail PR, Audemard F, Bowman SA, Eisner PN, Perez-Cruz C (1991) The stratigraphic signatures of tectonics, eustasy and sedimentology_an overview. In: Einsele G, Ricken W, Seilacher A (eds) Cycles and events in stratigraphy. Springer, Berlin Heidelberg New York, pp 617-659

Weedon GP, Coe AL, Gallois RW (2004) Cyclostratigraphy, orbital tuning and inferred productivity for the type Kimmeridge Clay (Late Jurassic), southern England. J Geol Soc London 161:655-666

Wignall PB (1991) Test of the concepts of sequence stratigraphy in the Kimmeridgian (Late Jurassic) of England and northern France. Mar Petrol Geol 8:430-441

Wildi W, Funk H, Loup B, Amato E, Huggenberger P (1989) Mesozoic subsidence history of the European marginal shelves of the alpine Tethys (Helvetic Realm, Swiss Plateau and Jura). Eclogae Geol Helv 82:817-840

Williams CJ (2001) Integrated stratigraphic correlation of the Upper Jurassic: links to sea-level and climate change. Unpublished $\mathrm{PhD}$ thesis, University of Oxford, Great Britain, pp 1-196

Williams CJ, Hesselbo SP, Jenkyns HC, Morgans-Bell HS (2001) Quartz silt in mudrocks as a key to sequence stratigraphy (Kimmeridge Clay Formation, Late Jurassic, Wessex Basin, UK). Terra Nova 13:449-455

Ziegler PA (1989) Evolution of the North Atlantic: an overview. In: Tankard AJ, Balkwill HR (eds) Extensional tectonics and stratigraphy of the North Atlantic margins. Am Assoc Petrol Geol Mem 46:111-130

Ziegler PA, van Horn B (1989) Evolution of the North Sea rift system. In: Tankard AJ, Balkwill HR (eds) Extensional tectonics and stratigraphy of the North Atlantic Margins. Am Assoc Petrol Geol Mem 46:471-500 